Florida International University FIU Digital Commons

7-24-2003

\title{
Challenging the "tragic mulatta" : the construction of biracial female identity in Quicksand, Passing, and Their eyes were watching God
}

Kyla Racquel Crowther

Florida International University

DOI: $10.25148 /$ etd.FI14061549

Follow this and additional works at: https://digitalcommons.fiu.edu/etd

\section{Recommended Citation}

Crowther, Kyla Racquel, "Challenging the "tragic mulatta" : the construction of biracial female identity in Quicksand, Passing, and Their eyes were watching God" (2003). FIU Electronic Theses and Dissertations. 2673.

https://digitalcommons.fiu.edu/etd/2673 
FLORIDA INTERNATIONAL UNIVERSITY

Miami, Florida

CHALLENGING THE "TRAGIC MULATTA":

THE CONSTRUCTION OF BIRACIAL FEMALE IDENTITY IN

QUICKSAND, PASSING, AND THEIR EYES WERE WATCHING GOD

A thesis submitted in partial fulfillment of the

requirements for the degree of

MASTER OF ARTS

in

ENGLISH

by

Kyla Racquel Crowther

2003 
To: Dean Arthur W. Herriott

College of Arts and Sciences

This thesis, written by Kyla Racquel Crowther, and entitled CHALLENGING THE "TRAGIC MULATTA": THE CONSTRUCTION OF BIRACIAL FEMALE IDENTITY IN QUICKSAND, PASSING, AND THEIR EYES WERE WATCHING GOD, having been approved in respect to style and intellectual content, is referred to you for judgment.

We have read this thesis and recommend that it be approved.

Bruce Harvey

Marilyn Hoder-Salmon

Katharine Capshaw Smith, Major Professor

Date of Defense: July 24, 2003

The thesis of Kyla Racquel Crowther is approved.

Dean Arthur W. Herriott College of Arts and Sciences

Dean Douglas Wartzok University Graduate School

Florida International University, 2003 


\section{ACKNOWLEDGMENTS}

I would like to thank my major professor, Dr. Kate Capshaw Smith, to whom I am deeply indebted for her willingness to help with this project despite her busy schedule. I would also like to thank my committee members, Dr. Bruce Harvey and Dr. Marilyn Hoder-Salmon, for taking time out of their summer vacations to read this thesis.

I am grateful to God for bringing me through this arduous process and consistently providing me with strength and guidance.

Finally, I thank my husband, without whose support in the form of encouraging words and midnight trips to 7-11 for Mountain Dew and taffy this thesis might never have been completed. 


\author{
CHALLENGING THE "TRAGIC MULATTA": \\ THE CONSTRUCTION OF BIRACIAL FEMALE IDENTITY IN \\ QUICKSAND, PASSING, AND THEIR EYES WERE WATCHING GOD \\ by
}

Kyla Racquel Crowther

Florida International University, 2003

Miami, Florida

Professor Katharine Capshaw Smith, Major Professor

The purpose of this study was to analyze the ways in which Harlem Renaissance-era novelists Nella Larsen and Zora Neale Hurston defy the "tragic mulatta" as a literary convention in their novels Quicksand, Passing, and Their Eyes Were Watching God. They seek to transform a tradition that not only perpetuates and reinforces essentialist notions of "blackness" and "whiteness," but also disregards the authenticity of a biracial identity. Through their revisions of this prototype, Larsen and Hurston advocate the construction of a biracial female identity for their mulatta characters that empowers them to resist the racial/gender stereotypes historically imposed upon them. By positing the need for multiplicity as opposed to a divided self, these authors resist essentialism and challenge the definition of "true womanhood." 


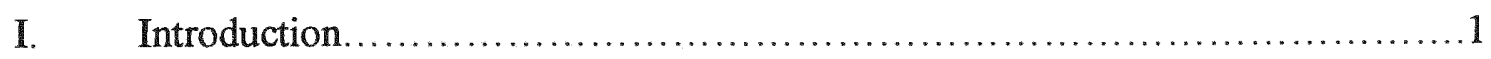

II. The "Tragic Mulatta": Evolution of a Literary Stereotype ......................8

III. Self-Image and Sexuality in Nella Larsen's Quicksand ........................29

IV. Subjugation and Self-Validation in Nella Larsen's Passing .....................54

V. The Realization of Biracial Female Identity in Zora Neale Hurston's

Their Eyes Were Watching God ........................................... 70

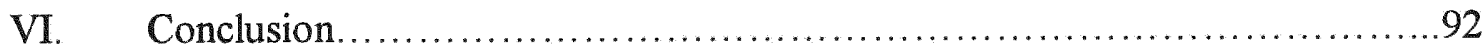

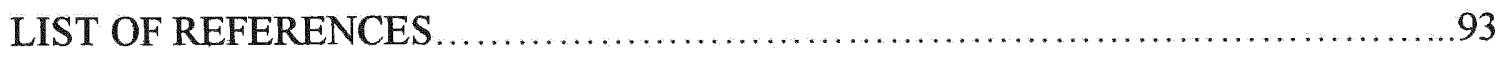




\section{Introduction}

The Harlem Renaissance, which is considered to have occurred between approximately 1919-1937 , marks an important historical period for African-Americans. The unprecedented flowering of music, art, poetry, and fiction within black intellectual circles represented a quest for cultural roots and a general celebration of identity, not merely in Harlem (though that was the movement's center), but across the country and into other countries as well.

In Black Culture and the Harlem Renaissance, Cary D. Wintz asserts that "[t]he Harlem Renaissance was basically a psychology - a state of mind or an attitude-[of people who] shared... a consciousness that they were participants in a new awakening of black culture in the United States" (2). Hence, "[r]ace and race-consciousness were constant themes in the literature of the Harlem Renaissance" (4). The time period allowed opportunity for closer examination of race issues, and writers took advantage of it with great intensity.

Of particular interest are the works written by females during this period. Gloria Hull states in Color, Sex, \& Poetry: Three Women Writers of the Harlem Renaissance, that the Harlem Renaissance, "despite its veneer of equal opportunity, was a time when not only Harlem and the Negro, but men as usual were 'in vogue"' (10). As such, it was considerably more difficult for women both to express and be recognized for their ideas and insight. However, these writers were determined to be heard. Their works focus primarily on issues specific to African-American women, not all African-Americans. 
After all, as Hull points out, "[t]he lives of Afro-American women have always been determined as much by their gender as by their race" (20). Historically, black females have been doubly marginalized, simultaneously resisting oppression based on both of the aforementioned categories. Therefore, the forging of female identity is a central concern in many texts of the era, including those of Nella Larsen, Zora Neale Hurston, Jessie Fauset, and others.

It is not that black female writers ignored the concerns of African America as a whole. Conversely, Richard Yarborough contends that "[t]he most important battleground of racial conflict...lie[s] within the individual, and an understanding of that conflict entails a complex vivisection of identity itself" (119). These authors understood that racial identity, when subjected to this type of "vivisection," would reveal itself to be much more malleable than historical constraints and stereotypes previously allowed it to be.

Thus, the mutability of racial identity became an issue of primary importance for many women writers of the Harlem Renaissance, one which required them to challenge preconceived notions about African-American females. Critics often see women writers of this period as turning to what Cheryl Wall terms "anachronistic" forms in order to evade the stereotype of black women as sexually promiscuous. The genteel school of writing became prevalent as a means of disentangling black women from the stereotype of lewd sexuality and presenting a more positive image, although this often resulted in the use of another prescribed characterization, particularly that of the "tragic mulatta." Nella Larsen and Zora Neale Hurston, however, sought to react against all stereotypes attributed to black women. As such, their novels staunchly defy the tradition of the 
"tragic mulatta" as a literary convention. The mulatta ${ }^{2}$ has long been depicted in literature as a woman whose constant inner turmoil based on lack of racial definitiveness leads to despair and death. She is an intentionally ambiguous figure, used to suggest that if one cannot readily fit into either of the socially constructed institutions of "black" or "white," one has no discernible identity. However, as Anselm Strauss notes in Mirrors and Masks: The Search for Identity, "[i]t is in the areas of ambiguity that transformations take place" (26). Larsen's novels Quicksand (1928) and Passing (1929) and Zora Neale Hurston's Their Eyes Were Watching God (1937) seek to transform a literary tradition that both perpetuates and reinforces essentialized notions of "blackness" and "whiteness" into a new tradition that resists essentialism and recognizes the significance of biraciality.

Self-designations are important vehicles for the self-empowerment of oppressed people (Helms xxiii). Because the tragic mulatta is consistently depicted as the pathetic victim of a divided black/white self, she cannot assert either "self-designation," and is therefore powerless to overcome racial and gender stereotypes that lend to her inevitable downfall. Larsen and Hurston attempt to rectify this problem by offering such a "selfdesignation" for their revised mulatta characters: the construction of a biracial female identity. In Racially Mixed People in America, Maria Root asserts that biracial identity is primarily defined by "a groundedness in... multiplicity" (204), which defies notions of racial essentialism. Larsen and Hurston advocate a biracial identity, then, because of its power to refute the essentialist notions upheld by the tragic mulatta stereotype.

In his review of Thadious Davis's biography on Nella Larsen, George Hutchinson notes that "current studies of [Larsen's] fiction firmly discount the significance of biracial...identity" in Quicksand and Passing, typically dismissing it "as merely a 
metaphor for more 'important' concerns [such as] black and/or female identity, in particular" (345). Similarly, most of the scholarship on Hurston's Their Eyes Were Watching God focuses on Janie Crawford's position within an all-black community and often ignores her biracial status altogether. However, it is important to note that as women of mixed-race descent, both Larsen and Hurston have a particular interest in the representation of the mulatta character, and recognize more than anyone her potential to be a site for change. Their revisions of the tragic mulatta clearly posit the need for multiplicity, which not only challenges racial/gender stereotypes, but also confronts "the American racial ideology that renders biracial subjectivity invisible, untenable, or fraudulent" (Hutchinson 330).

Furthermore, the aspect of "multiplicity" applies to their characters' feminist identities as well. The construction of a biracial female identity certainly involves the claiming of a racial identity that is not based on stereotypes, but also includes drawing and learning from all facets of one's heritage to aid in resisting stereotypical notions of womanhood that impede the construction of positive self-definitions for all females. In recent years, black feminist criticism has had a separate trajectory from white feminism because of the latter's tendency to lose sight of the necessity for "total freedom" for all women in favor of white "female self-aggrandizement" (Smith 49). However, Larsen and Hurston understand that the realization of multiplicity involves challenging notions of female essentialism and confronting ideologies that prevent the liberation of all women. As bell hooks contends in Ain't I A Woman: black women and feminism,

[r]esolution of the conflict between black and white women cannot begin until all women acknowledge. . 
women's continued bondage to materialistic patriarchal principles, and passive acceptance of the status quo. . The process begins with. . the individual woman's refusal to accept any set of myths, stereotypes, and false assumptions that deny the shared commonness of her human experience; that deny her capacity to experience the Unity of all life; that deny her capacity to bridge gaps created by racism, sexism, or classism; that deny her ability to change.

Thus, through the authors' resistance of the "myths, stereotypes, and false assumptions" associated with the tragic mulatta tradition, they also use their biracial characters as vehicles for analyzing the resistance of all females against stereotypical categorization, in terms of race, gender, and/or class. Larsen and Hurston challenge the historical definition of "true womanhood" and reassert the necessity for the "total freedom" of women.

A thorough discussion of the tragic mulatta's literary origins and development is vital in terms of understanding the motivation behind Larsen's and Hurston's revisions. Chapter Two traces the evolution of this literary stereotype, detailing her historical characterization and explaining how it contributes to the essentialist notions of race and "true womanhood" that these authors later staunchly challenge. Chapter Three analyzes Larsen's Quicksand, and explores Helga Crane's struggle to assert a positive selfidentification as a biracial female in terms of her self-image and sexuality. Chapter Four analyzes Larsen's Passing, in which Clare Kendry's pursuit of a biracial female identity 
threatens to destroy Irene Redfield's stable social position, self-image, and marriage. Chapters Three and Four also employ a discussion of the reasons behind Larsen's characters' failures to achieve the goal of a biracial female identity. Chapter Five analyzes Zora Neale Hurston's Their Eyes Were Watching God, whose protagonist, Janie Crawford, achieves the biracial female identity that Helga Crane, Clare Kendry, and Irene Redfield aspire to but never attain. This chapter discusses solutions to the problems of self-image, sexuality, marriage, patriarchal oppression, and womanhood raised in Larsen's earlier novels.

Through their revisions of the tragic mulatta, both authors dislodge preconceived notions of "blackness" and "whiteness" from biological determinism; they become less essentialized, stereotypical terms than terms creatively in flux. Larsen and Hurston refute stereotypical assumptions about black/white female character, identify the necessity for autonomy in the face of conformity, and empower all women to discard historical limitations imposed upon them, forge new identities, and create their own destinies. 


\section{Endnotes}

${ }^{1}$ See Black Culture and the Harlem Renaissance by Cary D. Wintz. The author explains that while "the precise chronological limits of [the Harlem Renaissance] are somewhat difficult to define" (1), scholars generally agree that it was prompted by the race riots of 1919 and "extended well into the 1930 s and included the later works of Zora Neale Hurston [and other writers who] consciously identified with the Renaissance" (2).

${ }^{2}$ The term "mulatta" refers to a female of mixed race or ancestry. While the more widely used term for all persons of mixed ancestry is "mulatto," this work focuses specifically on females, and as such, "mulatta" will be used exclusively throughout. 
The "Tragic Mulatta": Evolution of a Literary Stereotype

In order to understand the reasoning behind Larsen's and Hurston's revisions, a discussion of the tragic mulatta's literary evolution is pivotal. Such a discussion will explain how her historical characterization perpetuates the essentialized notions of race and "true womanhood" that prompt Larsen and Hurston to advocate the construction of a new biracial female identity for their revised mulatta characters in Quicksand, Passing, and Their Eyes Were Watching God.

The tragic mulatta has deep roots in American literary history, beginning with nineteenth-century abolitionist fiction. The character does undergo some revision as time passes. However, as Judith R. Berzon notes in Neither White Nor Black: The Mulatto Character in American Fiction, while the tragic mulatta later becomes known as one "in conflict over the warring parts of [her] own nature," the character starts out as one "at odds with a society that exploits and oppresses [her] as if [she] were a common slave, or, worse, abuses [her] sexually in a manner rarely endured by the full-blooded field slave" (101). In the initial depictions of the tragic mulatta character, there is no real internal "warring," because the author usually acknowledges that her "whiteness" clearly dominates her "blackness."

Lydia Maria Child, white writer and abolitionist, and reportedly the "first American writer to fictionalize miscegenation" (Yellin 71), is widely credited for inventing the literary stereotype that would later become known as the tragic mulatta. Rosalie and her daughter, Xarifa, the main characters in Child's short story "The 
Quadroons" (1842), set the precedent for a subsequent plethora of mulatta characters typified in similar "tragic" manners throughout literature.

In her biography of Lydia Maria Child, Carolyn Karcher notes that the author's intentions regarding the inception of the tragic mulatta were admirable, in that she desired to "attract unsympathetic consumers" to the plight of the black slave (335). This lovely lady, meek and fragile, possessed all the grace and elegance attributed to white women, yet her life would inevitably end in despair and death because the "black" portion of her biological existence denied her true freedom and happiness. She was obviously created as a means of appealing to the white reader's sensitivity. In her article "Slavery, Race, and the Tragic Mulatta," Elizabeth Fox-Genovese points out that "[t]he notion that a few drops of blood, of which the tragic mulatta manifested no external sign, could determine a woman's fate understandably chilled readers, as indeed it was intended to" (795). However, while Child's tactic was temporarily successful, it was also intrinsically problematic. Carolyn Karcher contends that while Child may have been successful in garnering sympathy for the tragic mulatta's plight, it came "at the cost of dangerous concessions to the very prejudices and misconceptions abolitionists sought to overcome" (343). As her renderings of the mulatta consistently involved attributes historically associated with "whiteness," Child was actually encouraging her readers to sympathize with that aspect of the character. The mulatta's "tragedy" becomes not her sexual victimization, or oppression by white patriarchal ideology, but rather the "few drops of black blood" that keep her in that unfortunate position.

In Women \& Sisters: The Antislavery Feminists in American Culture, Jean Fagan Yellin asserts that Child's tragic mulatta is "a slave woman of mixed race who wants to 
conform to patriarchal definitions of true womanhood but is prevented from doing so by the white patriarchy" (53). In "The Quadroons," Rosalie's long-time lover, Edward, represents the white patriarchy of which Yellin speaks. Though he and Rosalie love each other, cohabitate, and share a daughter, they are not permitted by law to marry, as Rosalie is a quadroon". This is not, however, the only aspect of "true womanhood" denied Rosalie because of her mixed-race status. While Yellin states that "marriage [is] the traditional true woman's only goal" (72), Barbara Welter argues otherwise in her article "The Cult of True Womanhood: 1820-1860." According to Welter,

[t]he attributes of True Womanhood. . could be divided into four cardinal virtues - piety, purity, submissiveness and domesticity. . Without them, no matter whether there was fame, achievement or wealth, all was ashes. With them [women were] promised happiness and power.

Thus, while Rosalie is described as "the daughter of a wealthy merchant of New Orleans, highly cultivated in mind and manners, graceful as an antelope, and beautiful as the evening star" (Child 1), she is still a mulatta, and thus the title of "true woman" will forever elude her.

It is not that Rosalie does not try to adhere to the characteristics of true womanhood. Contrarily, Karcher allows that "Rosalie's conscience [is] as strict as any white woman's" (336). She insists that her union with Edward is "sanctioned by Heaven, though unrecognised on earth" (Child 2), which demonstrates her desire to be "pure," as dictated by the code of true womanhood. However, as she engages in sexual relations 
out of wedlock, and henceforth bears an "illegitimate" child, purity can never truly be ascribed to her. Piety also eludes her for the same reasons. Rosalie willingly submits to Edward's wishes, even when they include marriage to another woman-blond-haired, blue-eyed Charlotte-for the purpose of furthering his political endeavors. Child even writes that Rosalie

pitied his fair young bride, and would not be tempted to bring sorrow into her household by any fault of hers. Her earnest prayer was that she might never know of her existence.

Although she has loved Edward for years, she gives him up completely, even refusing to have secret sexual relations with him, as "her spirit [is] too pure to form a selfish league with crime" (3). However, despite Rosalie's honorable attempts at virtue, she ends up distraught and alone, "denied the joys of true domesticity" (Yellin 72). This paradox is the very essence of Rosalie's "tragic" character. Yellin notes that "[t]he pathos of the Tragic Mulatt[a] rests in the contradiction between her sincere efforts to adhere to the patriarchal definition of true womanhood and the patriarchy's insistence that she violate this norm" (72). Rosalie knows she is doomed to live a life of unhappiness. Child writes that "[a]t last, the conflicts of her spirit [prove] too strong for the beautiful frame in which it [dwells]" (5), and she dies, the epitome of tragedy.

Xarifa, Rosalie's daughter, suffers a similar fate. Though she is biologically an octoroon $^{2}$, not a quadroon, she still "belong[s] to a proscribed race; and though the brown color on her soft cheek [is] scarcely deeper than the sunny side of a golden pear...it [is] sufficient to exclude her from virtuous society" (Child 5). Up to this point, Xarifa has 
been "the central point of all [her father's] warmest affections" (5), "accustomed to the fondest indulgence, [and] surrounded by all the refinements of life" (6), including dancing lessons, music lessons, and gifts. However, years after Rosalie's death, her life makes an abrupt turn toward heartache. She follows precisely the pattern outlined in Jules Zanger's "The Tragic Octoroon":

Central to the stereotyped plot is the element of reversal whereby the heroine is suddenly reduced. . . against all evidence of the senses, from aristocratic, pampered white heiress to Negro slave-from riches to worse than rags.

Xarifa's instantaneous "role reduction" occurs just after her father, attempting to drink his guilt and sorrow away, dies on the roadside, and his wife cruelly chooses to halt the privileges he had heretofore been lavishing upon his daughter. Shortly thereafter, Xarifa is "ruthlessly seized by a sheriff, and placed on the public auction-stand" (Child 6) after it is discovered that her white grandfather's estate still lays claim to her. The first replication of her mother's tragic mulatta status, Xarifa loses her white lover and subsequently dies, "a raving maniac" (7).

Carolyn Karcher believes that "The Quadroons" is "dangerously flawed" because "its heroines' preference for white lovers suggests a repudiation of their African roots" (336). Her use of the word "preference," however, indicates that Child's characters are given a choice, which they certainly are not. The more dangerous flaw seems to be, rather, the mulattas' repudiation of identity, in that they are static, mechanical shells following a formulaic literary prescription. They do not fit into the societally constructed 
categories of "black" or "white," and as such, are presented as flat and powerless characters. Moreover, Child's next short story, "Slavery's Pleasant Homes" (1843) reinforces the myth laid in place by "The Quadroons" although its principal tragic mulatta, Rosa, rejects the affections of a potential white lover in favor of a fellow mulatto slave.

Rosa is described as "elegantly formed, and beautiful as a dark velvet carnation" (Child 1). While she is "darker-hued" (Karcher 337) than her predecessors, Rosalie and Xarifa, her skin is still light enough for the blush in her cheeks to be as noticeable as "claret through a bottle in the sunshine" (Child 1). Once again, as with Rosalie in "The Quadroons," Child places her tragic mulatta in competition with a white woman, this time Rosa's half-sister, Marion. Marion, "as delicate as the white Petunia blossom" (1), treasures her enslaved sister until she discovers that her husband, Frederic Dalcho, has been seeking out the young girl's affections. Frederic, jealous of the fact that Rosa is in love with his quadroon half-brother, George, rapes the young slave girl, then flogs her repeatedly when he discovers that her heart still belongs to her lover (with whom she has "uttered the marriage vow. . in the silent presence of the stars" (Child 2), thus establishing her desire for purity). Rosa "faint[s] under the cruel infliction, which [is] rendered doubly dangerous by the delicate state of her health [pregnancy]" (3), and dies tragically. Hence, Rosa, the enslaved mulatta, despite her attempts to be pure and virtuous, is sexually victimized, impregnated, and subsequently killed by her white master, further establishing the notion that the tragic mulatta's quest for "true womanhood" is inevitably halted by the oppressive white patriarchy. 
Both Yellin and Karcher contend that Child wishes to draw a parallel between the tragic mulatta and her white female counterpart, by showing that both are enslaved and oppressed by the same controlling force. While Charlotte of "The Quadroons" and Marion of "Slavery's Pleasant Homes" do not experience physical violation or enslavement, Child portrays them, in a sense, as helpless victims of their husbands' infidelity. Yellin allows that Marion, "although [Frederic's] wife, is powerless to command his exclusive sexual attention or to prevent him from molesting [Rosa]" (73). Similarly, Charlotte, though devastated when she learns of Edward's attachment to Rosalie, cannot demand his faithfulness to her either. However, it is evident that the white females have much more power and freedom than the tragic mulattas.

In Ar'n't I a Woman?: Female Slaves in the Plantation South, Deborah Gray White notes that, while Southern white women could not "right the wrongs done them. . .some did strike back...usually at their unwitting and powerless rivals" (41), something mulattas could never do. Charlotte, for example, actually exacts revenge on Edward by asserting power over Xarifa, taking away her privileges and sending her back into a life of slavery. Marion is permitted to argue with her husband (albeit to no avail) concerning his treatment of Rosa, and, upon discovering the truth about his feelings for the young mulatta, "[gives] her a blow" (Child 2) that effectively establishes her dominant position. Thus, through Child's intimation that the white female characters in her stories are as equally deserving of sympathy as the mulattas, she allows "her white female readers to identify with the victim by gender while distancing themselves by race," which prevents them from "confronting a racial ideology that denies the full humanity of nonwhite women" (Yellin 71). Because the plights of the white woman and the mulatta, though 
the latter far supersedes the former in terms of harshness and degradation, are meant to garner equivalent amounts of sympathy from readers, "this can be interpreted... as an endorsement of white racism" (Yellin 73) rather than an unearthing of the real tragedy of slavery.

The tragic mulatta motif carries on in several other antebellum abolitionist works, starting with Harriet Beecher Stowe's Uncle Tom's Cabin (1852), perhaps the most renowned abolitionist work in history. In the Preface to Uncle Tom's Cabin, Stowe writes that the object of the novel "is to awaken sympathy and feeling for the African race" (Stowe 3). However, as critic Louisa McCord asserts,

Seeming to forget that her principal task is the defence of the negro [sic], decidedly the majority of the persecuted individuals brought forward for our sympathy, are represented as whites, of slightly negro descent, not negroes.

Like Child's, Stowe's tragic mulattas are presented as sympathetic figures because of their white characteristics. Eliza, the principal tragic mulatta, is a beautiful quadroon, like Rosalie. Stowe comments briefly on the characteristics that make Eliza and others like her admirable figures:

The traveller in the south must often have remarked that peculiar air of refinement, that softness of voice and manner, which seems in many cases to be a particular gift to the quadroon and mulatto women. Those natural graces in the quadroon are often united 
with beauty of the most dazzling kind, and in almost

every case with a personal appearance prepossessing

and agreeable.

Here, Stowe's "aside" none too subtly reminds readers that mulattas, as opposed to "fullblooded" Negroes, are more like the women they are familiar and comfortable withwhite women. Furthermore, as if to reassure them of Eliza's worthiness, Stowe asserts that she is "a petted and indulged favorite" (17) of her white mistress.

Stowe does attempt to resist one stereotype in her characterization of Eliza. In "Strategies of Black Characterization in Uncle Tom's Cabin and the Early AfroAmerican Novel," Richard Yarborough remarks that "Stowe especially emphasizes the obsessive strength of Eliza's love for her son, Harry" in order to "counter the claim that female slaves lack maternal instincts" (51). However, as Yarborough explains, this resistance on Stowe's part actually reinforces the tragic mulatta stereotype. Admittedly, it is because of Eliza's love and devotion to her son that she gains the strength to run away and save him from a bitter life of slavery. Stowe writes that "the touch of [her son's] warm arms... seemed to add fire and spirit to her movements" (Stowe 55), thereby empowering her to make the "desperate retreat across the river" to safety (67). Despite Eliza's obvious maternal instincts and determined spirit, she is not presented as a paragon of power for mulatta women. Rather, as Yarborough points out, Stowe emphasizes Eliza's whiteness because of "her inability to view... heroism in any but 'white' terms" (51). Eliza is not a revised tragic mulatta; she is able to escape only in that her "whiteness" has given her inner strength and bravery. Also, Yarborough adds that "her maternal dedication...constitute[s] virtually the entire range of her characterization; we 
see little real psychological depth or intellectual vigor" (52). This is Eliza's real "tragedy."

While Stowe notes that "[i]t is impossible to conceive of a human creature more wholly desolate and forlorn than Eliza" (54), she still does her level best to accomplish this with Cassy. Cassy, the other major tragic mulatta in Stowe's work, who turns out to be Eliza's mother, is accurately described by Berzon as "[o]ne of the most unforgettable portraits of the tragic mulatt[a] character" (101). Her history resembles Xarifa's in "The Quadroons," as she is brought up in wealth and comfort, and then abruptly sold into slavery after her father's death to compensate for his debts. She is sold to Henry, a white man whom she loves "better than [her] own soul" (Stowe 372). Like Child's Rosalie and Edward, Cassy and Henry's marriage vows are spoken outside of a church. She is his slave, not his wife, and their two beautiful children are his property as well. He later sells them all, which spirals Cassy into a life of oppression, abuse, and separation from everything and everyone she has ever loved.

What is most interesting about Cassy is her presentation as a bitter, angry woman as opposed to a meek, lowly model of virtue. She speaks out harshly about her past, unlike Child's Rosalie, who accepts her lot with nary a word of protest. However, despite her rebellious attitude, Cassy still suffers from the "inability to control [her] own fate" (Berzon 104). Berzon adds that "[c]haracters like Cassy more legitimately deserve to be thought of as 'tragic' because they are given the stature to go along with the concept" (104). Cassy's physical description reveals the true nature of her tragedy:

[Hers] was a face that, once seen, could never be forgotten,--one of those that, at a glance, seem to 
convey to us an idea of a wild, painful, and romantic history. . . [S]he must once have been beautiful; but her face was deeply wrinkled with lines of pain, and of proud and bitter endurance. (Stowe 360)

Naturally, Stowe is careful to emphasize that her tragedy lies more in the fact that she is unable to live in the luxurious world of "whiteness" than in the fact that she has been mistreated and oppressed for years. Upon his first encounter with Cassy, Tom observes from her "air and bearing, that she belong[s] to [the white] class," and cannot imagine "how or why she could be fallen to... degrading circumstances" (Stowe 361). One would think that Cassy's bitterness would be directed toward the white world in general for her sad lot in life. However, Stowe notes that Cassy walks around "with an air of scorn, as if she despise[s] both the work and the disgrace and humiliation of the circumstances in which she [is] placed" (361). She acknowledges without question that Tom is "a miserable slave," but states that she is "a lower one than [he] can ever be" (Stowe 367) because of her mixed-race status. Cassy considers it far more tragic that she, a former woman of privilege, should now be considered a lowly slave.

Hence, both Eliza and Cassy are depicted again as tragic mulattas "prevented by slavery from complying with patriarchal definitions of true womanhood" (Yellin 76). Cassy is denied marriage to her lover, thereby eliminating piety and purity from her life, and is then separated from her two children, whom she loves more than anything. Eliza, too, is denied the joys of true womanhood, first by being separated from her husband, and then because she is threatened with the loss of her son. Interestingly, Cassy and Eliza do not die at the end of the novel. Stowe offers a tidy resolution that reunites mother and 
daughter in Canada, where "Eliza's steady, consistent piety" causes Cassy to "[yield] at once, and with her whole soul, to every good influence" (Stowe 439). As Jean Fagan Yellin observes in 'Doing It Herself: Uncle Tom's Cabin and Woman's Role in the Slavery Crisis," Cassy's "abrupt conversion" denotes her static characterization (99). She is not a character of depth or complexity. Like Eliza, who readily drops her sheath of bravery and initiative once domestic life is available to her again, Cassy simply accepts her newfound destiny without "agonizing over her decisions" (Yellin 99). There are no alternatives offered them other than slavery or a life in line with the white patriarchal definition of true womanhood.

White abolitionist authors were not the only ones to utilize the tragic mulatta protagonist in their writings. She emerged in many black-authored texts as well. Subsequent representations of the tragic mulatta in William Wells Brown's Clotel (1853), Harriet E. Wilson's Our Nig (1859), and Harriet Jacobs' Incidents in the Life of a Slave Girl (1861), do little to revise her static characterization, however. In her article "Race, Womanhood, and the Tragic Mulatta: An Issue of Ambiguity," Christine PalumboDeSimone remarks that the above novels each feature tragic mulattas who, despite 'sympathetic portrayals'. . [are] little more than the embodiment of what had become the standard literary representation of the mixed-race character:

female, observably white in all regards, and dazzlingly beautiful, the mulatta suffers from a melancholy of the blood that leads to tragedy. 
Furthermore, as Judith Berzon has said, "[a]uthors of mulatto fiction. . do not give their female characters very great breadth or depth, or very many options" (Berzon 74), presumably because they cannot pinpoint an appropriate societal niche for them. Although, as with Cassy in Uncle Tom's Cabin, the tragic mulatta does have her more spirited moments that suggest momentary empowerment over the aforementioned "melancholy of the blood," such instances are brief and usually fizzle out as the author realizes the depiction is unrealizable. Such is the case with Clotel, William Wells Brown's fictional portrayal of the mulatta daughter Thomas Jefferson purportedly fathered, then sold into slavery. Her fair complexion and "features as finely defined as any of her sex of pure Anglo-Saxon" naturally render her "one superior to her position" on the slave auction block (Brown 47). Horatio Green purchases Clotel as "tears [well] in her eyes" (48), and after several directly plagiarized passages from Child's "The Quadroons," abandons her for a white woman and leaves her with a daughter, Mary. However, death does not come from a broken heart for Clotel as it did for her predecessor, Rosalie. Rather, after her daughter is sold into another home, Clotel exerts all her efforts into locating her, subsequently gets arrested, and dies trying to flee from a slave prison.

As Hilton Als notes in his introduction to Clotel, this mulatta's tragedy is the fact that she "gives birth to a child she cannot mother" (xix). However, despite her efforts to reclaim the maternal rights stolen from her by the oppressive white patriarchy, she becomes their next victim. More importantly, despite Brown's efforts to give his Clotel a less tragic end than that of Child's Rosalie, he can find no discernible place for her in society. In Clotel's last minutes of life, the "vast forest" into which she desperately tries 
to "bury herself" is also a metaphor for what her life would be like were she to survive (Brown 182). She obviously recognizes this, because she opts to jump over a bridge to a watery death.

Up to this point in literature, the tragic mulatta has been portrayed consistently as an enslaved woman who urgently seeks but can neither attain nor maintain every aspect of "true womanhood." Her racial ambiguity lends to her pathetic position, as she belongs to neither of the societally established, essentialized categories of "black" or "white," though she typically desires to be welcomed into the latter margin. Of course, there are exceptions to this general rule of characterization, such as Frances E.W. Harper's Iola Leroy (1892).

Harper introduces her mulatta character in typical "tragic" fashion. Young Iola, a "beautiful...angel" with "long hair" and "blue eyes" (Harper 38-41), is cruelly ripped from her life of white privilege when her father dies and she suddenly discovers the "imperceptible infusion of negro blood in her veins" (114). Iola is subsequently thrown into a life of slavery, though it is noted several times that no one can believe that "[a] woman as white as she [could be] a slave" (58). However, Harper attempts to revise the tragic mulatta tradition in that after being freed from slavery, the "refined and lady-like" (57) Iola does not immediately wish to reclaim her position as a member of aristocratic white society. She adamantly refuses to identify with the "race who had been so lately associated in her mind with horror, aversion, and disgust" (111) and had collectively "consent[ed] to [her] abasement" (115). Furthermore, although she sees in Dr. Gresham "the ideal of her soul exemplified" and admits that "her heart. . . [is] entwining around 
him" (110-11), Iola will not accept his marriage proposal, because she cannot think "of giving or receiving love from one of that [white] race" (111).

Harper's subversion of stereotype, though, is still problematic, and laced with contradictions. First, as Hazel Carby notes, the novel advocates "a complete separation of the black community from the white world" (93). While Iola is definitely an improvement on the tradition of the tragic mulatta in that she does not suffer from "melancholy blood" and refuses to deny her black heritage, her repudiation of her white identity and general disdain for white people actually reinforce the binary thinking that plunged her into "tragedy" to begin with. Furthermore, even as Iola rejects her white racial heritage, she simultaneously upholds and practices the virtues of "true womanhood" previously established by the white hegemony, asserting that "the greatest need of the [black] race is...true women" (172). Finally, while her commitment to racial uplift ideology fulfills her to some extent, it also requires her to deny aspects of her identity. As Kevin K. Gaines asserts in Uplifting the Race, "[w]ithin uplift, black women cannot exist for themselves, but only insofar as they serve the utilitarian project of race building" (231). For example, Iola's assertion that she will only marry a black man requires her to foreground "race allegiance" rather than love, affection, or attraction. Because of these things, her characterization still upholds notions of racial/gender essentialism.

In The House Behind the Cedars (1900), Charles W. Chesnutt offers no impassioned pleas for sympathy for his mulatta protagonist, but, rather, defends her desire to rid herself of the "taint of black blood" via "concealment" (Chesnutt 127-28) through his description of the horrific events that occur when the concealment attempt 
fails. Rena Walden is Chesnutt's tragic mulatta, whose "ivory complexion" and "rippling brown hair" allow her to safely "pass" as a white woman without fear of detection (69). She even successfully fools her lover, George Tryon, and is willing to "bury the past [i.e. her racial heritage] in forgetfulness" in order to marry him (87). However, he discovers her mixed-race status and consequently rejects her, as "tinted beauty," though previously unnoticed, "had never appealed to him" (139).

Rena's subsequent downward spiral is reminiscent of previous tragic mulattas. One cannot ignore the fact that, once again, the mulatta is denied marriage and domesticity because of her "drop of black blood." However, Chesnutt's portrayal incites more complex issues as well. Absolute racial categories are called into question with the use of "passing" as a literary device, particularly since it turns out to be unsuccessful. Chesnutt augments the ridiculousness of essentialist notions of "black" and "white" through George Tryon's abrupt change of heart toward Rena, the professed love of his life and sole object of his affection, upon discovering her racial heritage:

In all her fair young beauty she stood before him, and then by some hellish magic she was slowly transformed into a hideous black hag.

In the foreword to Chesnutt's novel, William L. Andrews states that the fact that the novel ends "with [Tryon] willing to put aside the instinctive ready-made judgments of his training and environment in favor of his love for a 'black' woman indicates an abiding sense of hope in Chesnutt" (xix). It is important to note, however, that Tryon asserts that he will "make [Rena] white" upon taking her back (Chesnutt 208). He is not merely accepting her for who she is. The focus of the novel is on the difficult sacrifice 
made by the white "victim." Nonetheless, while Chesnutt may indeed be hopeful that a white man could actually embrace the tragic mulatta as an equal partner, he conceives of no such happy ending in his novel. In accordance with tradition, "the whole fabric of Rena's new life topple[s]. . with her lover's defection" (Chesnutt 193). Just as Tryon arrives to see her and take her back, she dies, reduced to the status of "cullud 'oman" (294).

Judith Berzon explains the "corresponding historical reality" of the newer version of the tragic mulatta, as exemplified in Chesnutt's work (Berzon 163):

Passing, as we have seen, is the most extreme form of the impulse toward assimilation. The identification with the white race-with the caste that is considered superior-is complete. . [T] $]$ he American dream of upward mobility can be sought through another form of identification with white middle-class America. The existence of a bourgeois class among the Negro group, a class that imitates the values, standards, and life-style of the white middle class, may fulfill the needs of. . black Americans who yearn for acceptance by, and assimilation into, white society.

Thus, in accordance with changing historical tradition, the postbellum literary tragic mulatta is not a product of the plantation, but of the black bourgeoisie culture. Outside of the confines of slavery that have previously denied her the right to assume a clear-cut racial identity, she opts to either assimilate into white society through "passing," or 
emulate as closely as possible the "white bourgeois world-its morals and its canons of respectability, [and] its standards of beauty" (Berzon 162-63). The black bourgeoisie culture affords her the opportunity to do the latter.

Jessie Fauset, a contemporary of Nella Larsen and Zora Neale Hurston, employs such a black bourgeoisie tragic mulatta in her novel Comedy: American Style (1933). Olivia Cary is so ashamed of her African-American heritage that she marries mulatto physician Christopher Cary, although she does not love him, because his light skin color will ensure that her children will never have to "acknowledge the strain of black blood which in considerable dilution would flow through their veins" (Fauset 37). Her first two children appear to be "white" in all physical regards, which pleases Olivia to no end, but when her third child, Oliver, arrives, with curly black hair and a "bronze gold complexion" (41), she is horrified. As he will never be able to pass as a member of the "dominant race" (40), she denies him maternal love, and is ultimately responsible for his suicide. The novel ends with Olivia's self-exile in Paris, bitter and lonely. Fauset does not depict Olivia's end as the result of a cruel fate that keeps her from achieving "whiteness," but, rather, shows that Olivia's tragedy lies in her belief "that Fate had perpetrated on her a very Cruel Hoax of which Oliver was the perpetual reminder" (205).

In Women of the Harlem Renaissance, Cheryl A. Wall states that Olivia "resolves that her children will be free of any racial stigma" (81). However, by subscribing to the societally ordained dichotomy of physically discernible "whiteness" as good / "blackness" as bad, Olivia ostracizes her son from her life, which consequently stigmatizes him in a way no schoolyard shriek of "nigger" could ever do. She publicly ignores him when he calls out for her, later explaining to him hotly that she does not wish 
for her friends to think she is "the mother of a wild Indian" (Fauset 201). She even manipulates him into acting as a butler when she has guests over. Oliver means nothing more to her than "the expression of her failure to be truly white" (205). Olivia never considers loving her son regardless of his coloring, as her husband and children unequivocally do, and as such, denies both herself and her son of a chance at formulating identities based on something other than absurd racial categorization. She is "never once... aware of having withheld from her child his natural heritage" (205). The biggest problem with this representation of the tragic mulatta is not only her disavowal of black heritage, culture, and identity, but also her depicted belief that the pursuit of a "white identity" is the only path in life that will bring one happiness and fulfillment. The text demonstrates quite clearly that Olivia Cary could have been happy as a biracial woman in a loving biracial family. Fauset asserts that, although Olivia separates herself from Oliver because of his color, "the two older children and his father would proudly conduct him anywhere" (42), indicating their disregard for racial categorization. Furthermore, while Olivia's primary motivation for hating her son is her fear that people will reject her, she ends up being rejected instead, while the community, "struck with [Oliver's] appearance and healthy grace, praise[s] him" and offers acceptance of his biracial status (42). Ultimately, Olivia's chance at happiness and fulfillment is tragically halted because of her staunch adherence to a false standard of unattainable "whiteness."

It is evident that Nella Larsen and Zora Neale Hurston have had enough of this weak, pitiful woman known as the tragic mulatta, and as such, they challenge this literary stereotype vehemently. They recognize that her primary weaknesses are her internalization of the superior white/inferior black dichotomy, belief that her "few drops 
of black blood" thwart her ability to experience the benefits of superior "whiteness" that she feels she deserves because of her appearance, and finally, her relentless aspiration toward a false ideal of Victorian "true womanhood" that renders her subjugated, sexually repressed, and truly "tragic" in every sense of the word. Larsen and Hurston posit the need for multiplicity and the construction of a biracial female identity for their "new and improved" mulatta characters, empowering them to overcome historical racial/gender stereotypes.

In Quicksand and Passing, Nella Larsen presents complex, intriguing mulatta protagonists (Helga Crane, Irene Redfield, and Clare Kendry) who challenge the historical characterization of the mulatta as having no depth or breadth. Furthermore, although her mulattas' experiences do not end happily, Larsen makes it clear that their "tragedies" result from their failure to attain their goal of a biracial female identity, not because they possess "black blood" that prevents them from completely achieving a false ideal of superior "whiteness."

Janie Crawford, the protagonist of Zora Neale Hurston's Their Eyes Were Watching God, exemplifies the "revised" tragic mulatta that Larsen and Hurston both attempt to create. Janie's struggle for self-actualization is successful, as she finds her role as a biracial female in relation to her community, and finds solutions to the problems of self-image, sexuality, marriage, patriarchal oppression, and womanhood raised in Larsen's novels. 


\section{Endnotes}

${ }^{1}$ The term "quadroon" refers to a person who is biologically one-quarter black, the child of a mulatto and a white. It has become obsolete.

${ }^{2}$ The term "octoroon" refers to a person who is biologically one-eighth black, the child of a quadroon and a white. It has also become obsolete. 
Self-Image and Sexuality in Nella Larsen's Quicksand

Nella Larsen's first novel Quicksand (1928) is the story of Helga Crane, a young woman seeking self-actualization as a biracial female in a society that categorizes everyone by race. Through her depiction of Helga's search for identity, Larsen staunchly refutes the notion that the character is a tragic mulatta. As Jacqueline McClendon asserts, Helga is not a woman who suffers from "persistent and uncontrollable urges of mixed blood," but one who "struggles for individualism and acceptance in a society that insists on conformity, in appearance as well as in behavior" (266-67). Through Helga's struggle to forge a positive self-image and come to terms with her sexual self as a biracial female, Larsen resists the historical racial and gender stereotypes laid in place by the tragic mulatta character by asserting that a woman can be beautiful and sexually expressive without being a sexual object. Helga's ultimate "tragedy" as a mulatta is not the result of "warring blood" or fate, but of her own foolish choice to participate in a segregated society and accept limiting categorization rather than staying true to her desire for a biracial female identity.

Helga Crane, a "delicate" and "attractive" young woman of twenty-three, whose "skin like yellow satin" provides a striking background for her "penetrating, dark eyes," certainly looks the part of the classic tragic mulatta (Larsen 2). However, the similarities end there. In "Nella Larsen's Use of the Near-White Female in Quicksand and Passing," Vashti Lewis notes that Helga's "biological heritage" is the first step in Larsen's "reversal" of the tragic mulatta stereotype, in that "her father is Black and her mother is 
white" (37). This can be attributed to the fact that she is modeled in part after her creator, herself the daughter of a Danish mother and an African-American father. As Thadious Davis notes in her biography of Nella Larsen, because of the author's own mixed-race background, she "infuses the text with a realistic treatment of the complexities of cultural experiences" (254). As such, Helga Crane is a refreshingly multifaceted mulatta character, distinctly at variance with the static figurations of her literary predecessors.

Some critics place Helga in the default classification of tragic mulatta because of her mixed racial heritage and because of the novel's decidedly unhappy ending. However, as Werner Sollors argues in Neither Black Nor White Yet Both: Thematic Explorations of Interracial Literature, being quick to label biracial characters as tragic mulattas "[advocates] as 'normal' a view of the world that divides people first of all into 'black' and 'white' - and hence ridicules intermediary categories as 'unreal'" (242). The novel's epigraph, excerpted from Langston Hughes's poem "Cross," lays the foundation for Larsen's examination of both the authenticity and intricacy of Helga Crane's "intermediary category":

My old man died in a fine big house.

My ma died in a shack.

I wonder where I'm gonna die,

Being neither white nor black?

Here, the speaker acknowledges his unique biracial status, which does not fit into essentialized notions of "blackness" and "whiteness" that dictated the destinies of his "old man" and "ma." His feelings clearly parallel Helga Crane's perception of her own biraciality in a culture that categorizes everyone by race. 
It is evident from the very beginning of Quicksand that Helga Crane is not a character who wishes to align herself too closely with the rigid constraints of categorization. The "tiny dissatisfied droop" (Larsen 2) of her lips in the novel's opening scene is evocative of her internal state. It is Naxos, the southern black college where twenty-three-year-old Helga is employed as a teacher, with which she is disgruntled:

The great community, she thought, was no longer a school.

It had grown into a machine. . It was. . now only a big knife with cruelly sharp edges ruthlessly cutting all to a pattern, the white man's pattern. . [I]t tolerated no innovations, no individualisms. Ideas it rejected, and looked with open hostility on one and all who had the temerity to offer a suggestion or ever so mildly express a disapproval.

Through Helga's resolute defiance of Naxos' mission to "uplift" (5) its black community to the status of the white bourgeois, Larsen establishes the character as a free thinker. While Kevin K. Gaines asserts that one of the intentions of uplift ideology was to turn "the pejorative designation of race into a source of dignity and self-affirmation" (3), Naxos appears to be more concerned with fitting its students into an essentialist mold, as designated by the white hegemony. Furthermore, Helga's disdain for Naxos' ideals expresses her innate aversion to any controlling force whose "intolerant dislike of difference" seeks to eradicate individual "charm and distinctiveness" (5). As a mulatta, Helga is aware of her "difference," and is equally mindful of the fact that, during her time at Naxos, her "charming personality [has been] smudged out" (5) because of its 
insistence on conformity to "white" standards. As such, "she [longs] for immediate departure" (5) so she can forge an identity for herself free of Naxos' restrictions.

Helga's first obstacle in her quest for identity is coming to terms with her physical self-image as a biracial female. Larsen's portrayal of Helga in this regard is particularly admirable, as she fiercely challenges preordained standards of beauty and appearance for both black and white women. In Ain't I A Woman: black women and feminism, bell hooks notes that, in contrast with the attributes of "[m]odesty. . and a submissive manner" (49) historically attributed to white women, "the predominant image [of black women] is that of the 'fallen' woman, the whore, the slut, the prostitute" (52). At Naxos, Helga and her fellow female teachers are expected to conform to regulations of "modesty" regarding all aspects of their physical appearance to avoid being labeled with one of those negative terms. While the tragic mulatta of the past would have willingly donned the required "[b]lack, brown, and gray...conventional garments" (Larsen 18) without complaint, for the purpose of being perceived as a pillar of (white) womanly virtue, Helga rebels against such absurdity. As Kimberly Monda observes in her article "Self-Delusion and Self-Sacrifice in Nella Larsen's Quicksand," Helga recognizes that the "acceptance of white, middle-class dress codes reveals... a dangerous form of selfhate" (26). To Helga, "the suppression of individuality and beauty" (Larsen 20) in order to avoid racial stereotyping only serves to validate the stereotype. Asserting the need for "A Plea for Color" (18), she refuses to submit to the school's standards, and instead abides by her own opinions as to what constitutes physical beauty.

While Monda suggests that "[g]orgeous, attention-grabbing colors might be read by racists as an immodest self-display" (27), Helga feels that they satisfy the "inherent 
racial need for gorgeousness" (Larsen 18). Helga is not supporting essentialism here. Rather, she thinks that women of color should emphasize their beauty by wearing garments that complement their individual skin shades, and as such critiques her fellow teachers harshly for their unflattering fashion choices, noting with obvious displeasure that dull, ashen hues are "ruinous" to "the luminous tones lurking in their dusky skins" (18). Although Helga's ubiquitously stated desire is "a goodly share of envious admiration" (11) from others, she refuses to obtain it by wearing garments that adhere to someone else's standard of beauty. She feels that the "dark purples, royal blues, rich greens, deep reds" and "trimmings" (18) with which she adorns herself should garner applause because they highlight her individual beauty, not necessarily objectify her as a sexually licentious woman.

Furthermore, Helga cannot understand why educated women choose to conform to a system of ideals that do not allow them the opportunity to express their unique beauty. She is horrified that her friend, fellow English teacher Margaret Creighton, attempts to change the texture of her "nice live crinkly hair, perfectly suited to her smooth dark skin and agreeable round features" (14). Patricia Hill Collins explains in Black Feminist Thought: Knowledge, Consciousness, and the Politics of Empowerment, that "prevailing standards of beauty-particularly skin color, facial features, and hair texture-is one specific example of how controlling images derogate African-American women" (89). Margaret is prompted to alter her hair drastically as a result of "binary thinking" that privileges "[w]hite skin and straight hair" over "dark skin. . and kinky hair" (89). Larsen augments the ridiculousness of this binary through Helga's description of Margaret's new hairstyle as "a dead straight, greasy, ugly mass" (14). Larsen is not 
critiquing straight hair here; to do so would be to reverse a binary that she only means to upset slightly. Larsen never suggests that straight hair itself is ugly. Helga's negative thoughts about Margaret's hairstyle derive from her resentment of the emulation of singular, fixed notions of what is beautiful. Margaret's hair is "dead" because she has robbed it of its natural, beautiful vitality by taming it into submission with an oily chemical substance. It is "ugly" because it is not her own, but a cheap imitation of what white society has deemed acceptable and attractive. Furthermore, as Meredith Goldsmith points out, "hair [is] a synecdoche of self" (103). Margaret's hair is representative of her internalization of false standards that inhibit her individuality and "life."

However, through her description of Helga's "pale amber skin" (Larsen 13) and "curly blue-black hair plentiful and always... falling unrestrained about her face and on to her shoulders" (2), Larsen attempts to upset this binary by depicting as beautiful a combination that does not fit the norms of beauty as established by the white hegemony. Helga has the desirable light skin, but she does not have straight hair, and does not try to "tame" her hair in order to meet someone else's standard of beauty. The fact that she allows her hair to fall "unrestrained" (2) indicates her defiance of the aforementioned light skin/straight hair white beauty norm.

Helga's rejection of white middle-class standards eventually leads her to Harlem, which, as Thadious Davis explains, "is the major physical landscape for the graphic explorations of Helga Crane's search for identity within an African-American world" (254). She is not, however, seeking to obtain an essential black identity. Disgusted with Naxos, whose "people yapped loudly of race...pride, and yet suppressed its most delightful manifestations, love of color [and] radiance" (Larsen 18), Helga longs to be in 
an environment that appreciates the variety and complexity of individual beauty, and in which she can embrace her multiplicity. 1920s Harlem seems to embody all that she is looking for. She quickly discovers, however, that Harlem society is not as accepting of individuality, or uniqueness, as she previously thought.

The black bourgeoisie society of Harlem, as exemplified through Helga's friend Anne Grey, is as critical of uniqueness as was Naxos. It would seem that Anne would appreciate individual style. After all, Helga notes that the "brownly beautiful" woman "[knows] what suits her and [wears] it with an air of unconscious assurance" (Larsen 45). However, Anne's exterior is indicative of her inner hypocrisy. Helga notes sardonically that she "carrie[s] herself as queens are reputed to bear themselves, and probably do not" (45), indicating that Anne holds herself to a standard that is not grounded in reality. She possesses a "deep and burning hatred" for white people, while simultaneously "[aping] their clothes, their manners, and their gracious ways of living" (48). Elaborating on this paradox, Helga notes that she is a self-ordained spokeswoman for race pride, though she "dislike[s] the songs, the dances, and the softly blurred speech of the race" (48), among other things. George Hutchinson suggests in "Quicksand and the Racial Labyrinth" that Anne's "seeming racial pride... covers up a sense of shame about being black and guilt about [her] own relationship to "whiteness"' (551). Because Helga lives with and spends the majority of her time with Anne, Anne's views influence Helga tremendously in her quest for identity as a biracial female.

As a woman with a mixed racial background, Helga recognizes the necessity for an appreciation, if not an embracing, of all facets of culture and ethnicity. Hence, Anne's "inconsistencies" fill Helga "with a great irksomeness" (Larsen 49). She disapproves of 
Anne's marked spoken disdain for all things "white" and inner disdain for all things "black." She expresses a desire "to be free of [Anne's] constant prattling of the incongruities, the injustices, the stupidities, the viciousness of white people" and her concurrent "disdainful contempt, tinged sometimes with a faint amusement" (48-49) for black people. Helga feels that Anne's hypocritical behavior is "dangerously malignant" (48) because it reinforces essentialist notions of "whiteness" and "blackness." Even while feeling "singularly apart" from the black community while out cabareting, Helga, unlike Anne, is able to appreciate the diversity of the race rather than lumping its members into a single identifiable unit. She observes the "moving mosaic" of people interestedly:

There was sooty black, shiny black, taupe, mahogany, bronze, copper, gold, orange, yellow, peach, ivory, pinky white, pastry white. There was yellow hair, brown hair, black hair; straight hair, straightened hair, curly hair, crinkly hair, woolly hair. She saw black eyes in white faces, brown eyes in yellow faces, gray eyes in brown faces, blue eyes in tan faces.

Despite Helga's admiration for the complexity of the people around her, however, she still feels that she does not belong. She does not want to assimilate completely into a black cultural identity any more than she wants to completely emulate white Victorian ideals. Like Larsen, she desires to "[publicize] her status as a mulatt[a]" because of her "fear of being absorbed into the masses, which she [views] as having the power to 
extinguish a concrete, autonomous, and productive self" (Davis 247). While she recognizes and appreciates the variety found within the black community, she knows that others, like Anne, do not see its variety. She is afraid to claim a black identity for fear that others will not see her as an individual, but as someone who fits into an exclusive, single definition of essential "blackness."

It is for this reason that Helga admires Audrey Denney, a mulatta who, according to Anne, "ought to be ostracized" by the black community "[b]ecause she goes about with white people... and they know she's colored" (Larsen 60). Helga sees in Audrey everything she wants to be: "a beautiful, calm, cool girl who [has] the assurance, the courage, so placidly to ignore racial barriers" (62). She listens to Anne's insulting remarks about the young woman's "obscene" tendency to hostess "parties for white and colored people together" with "a slightly sickish feeling" (61). While Anne feels that Audrey "plays up" to white people, Helga sees Audrey as someone who is honest and forthright about her mixed racial heritage and about the fact that she does not wish to be confined to one category or the other. The "flash of anger" (61) that courses through Helga's body as Anne is spewing out venomous judgments about Audrey indicates her own innate longing for a life that does not require her "to be one or the other." As Cheryl Wall asserts in Women of the Harlem Renaissance, "Audrey Denny [sic] [is] so appealing to her" because she "is unencumbered by the norms that define Negro ladies" (100). Thadious Davis allows that she circumvents "traditional roles for [all] women" as well (Davis 272). Helga has for Audrey the "envious admiration" that she desperately longs for herself (Larsen 62). She covets Audrey's ability to evade racial designations and wishes she could do the same without regard for the opinions of others. 
However, although Helga has earlier expressed a disregard, even disdain, for societally imposed racial categories, she cannot yet assume Audrey's confident status, as she fears the "contempt" of others that will accompany it (61). While Helga foregoes the experience of dancing and freeing herself to the sounds of the "extraordinary music" played by the "joyous, wild, murky orchestra" for fear of being seen as "a jungle creature" (59), she describes Audrey as dancing to the same music "with grace and abandon [and] with obvious pleasure" (62). Interestingly, when viewing Audrey, Helga only sees the music, not the dancer, as being "from the heart of the jungle" (62). She covets Audrey's comfortable, self-assured nature as she sways to the music.

Larsen revises the tragic mulatta stereotype again in that after resigning herself to Anne's pretentious middle-class environment, Helga begins to feel "shut in" and "trapped" (47) in her life as a black woman in Harlem. Unlike Harper's Iola Leroy, for instance, conforming to a life of static blackness and having no connection whatsoever to whiteness does not fulfill Helga, as a part of her identity is always required to be extinguished. Moreover, she begins to see the masses differently as a result of her confinement, admitting that "[t]here were days when the...brown faces about her stung her like a personal insult" (53). She is stunned to realize that "it [is] of herself she [is] afraid" (47). Helga's consistent discontentment with her environment of choice indicates that she fears identifying too closely with a specific racial group, lest she should begin to subscribe to the notion of a unitary, stifling identity. In this case, she fears becoming like Anne, which will completely eradicate her already waning sense of individuality as a biracial female. As Hutchinson points out, "Anne's very identity and security depend, in 
a sense, on the racial order that white society created, attempting in the process to make such persons as Helga Crane literally impossible" (553).

Helga's desire for acceptance and understanding as a biracial female leads her next to Copenhagen, Denmark, her late mother's place of origin. Larsen revises the tragic mulatta tradition here, however, in that Helga's attraction to whiteness is coded differently than that of her literary predecessors. Unlike Rena Walden in The House Behind the Cedars, for example, Helga is not motivated by a desire to "pass" and fully assimilate into white society to prevent being "shut out...by [her] color from much that is desirable" (Chesnutt 258). Rather, her journey to Copenhagen represents her desire for multiplicity, in that she wishes to be accepted and loved for who she truly is, and also embrace all aspects of racial/cultural identities. Recalling with fondness "the interest and admiration which her unfamiliar color and dark curly hair, strange to those pink, white, and gold people, had evoked" (Larsen 55) when she last visited at the age of eight, Helga begins "to dream delightful dreams" of a place where she will "be appreciated" for her uniqueness (56-57). Helga desires to be understood for the distinctive individual that she is, without being lumped into a single, exclusive racial category. When people who are aware of her biracial status admire and appreciate her, it strengthens her sense of self. It does seem, at first, that Copenhagen might be the perfect niche for her. Her aunt, Katrina Dahl, even asserts that she "must [wear] bright things to set off the color of [her] lovely brown skin" (68), a statement quite in keeping with Helga's earlier opinion.

In "Portraiture and Identity in Nella Larsen's Quicksand," Pamela E. Barnett states that "in Denmark Helga does not perform her notion of herself; she masquerades as the exotic other" (584). However, this statement suggests that Helga's life consists of a 
series of "performances," which undermines her obvious struggle throughout the novel to assert a true, multiple identity amid masses of people who support binary thinking. Also, it suggests that it is entirely Helga's choice to objectify herself in this manner. Admittedly, she is at first intrigued by the "lively and audible, but friendly, interest" (Larsen 76) her excessively decorative appearance garners. Clad in a "green velvet" dress that Helga describes as "practically nothing but a skirt," "barbaric bracelets," "dangling ear-rings," "beads," and even "rouge" on her first social outing in Copenhagen, Helga feels "really nervous and a little terrified, but manage[s] to present an outward smiling composure" (70). Her timid behavior in this scene indicates her discomfort with the image she is projecting. Despite her affinity for public admiration, Helga begins to feel a bit "resentful," because "the perfection of her own taste" (69) is violated as she assumes a new status as a "peacock" rather than a person (73).

While at first Helga feels that her desire for beauty and admiration without the stigma of "sexual object" is understood and appreciated by her Denmark relatives, she quickly learns that her position here is eerily similar to the one she occupied at Naxos. Just as the pretentious college's administration had commanded her to exemplify modest, pure "whiteness" in her physical appearance for the purpose of furthering its social agenda, Helga's aunt and uncle "[determine] the role that Helga [is] to play in advancing the social fortunes of the Dahls of Copenhagen" (Larsen 68) by dressing her up like a "veritable savage" (69) for the entertainment of their guests. Helga, however, is not as quick to remove herself from this position as she was at Naxos, because she desires to be with and be close to family members that love her and treat her well. After leaving Naxos, she attempted to seek help and refuge from her uncle, Peter Nilssen, but was 
rejected by his new white wife, whose "latent antagonism" caused Helga to feel like "an obscene sore" in her family, "at all costs to be hidden" (28-29). Because her Copenhagen relatives do not treat her this way, she temporarily overlooks their tendency to objectify and use her for their own selfish benefit.

Hence, Helga does not flee Denmark merely because of her discomfort with her newly exoticized body. As Barnett points out, "this role eventually reveals its demeaning, underlying assumptions" (584), which are far worse than being the center of constant admiration. Axel Olsen, the famous painter that Helga's aunt none too subtly implies she should marry, brings Helga to a realization of how people really perceive her. While she feels "naked... under his direct glance" (Larsen 86), his blunt assertion that she has "the soul of a prostitute" (87) is evidence of the fact that he cannot really see past her exterior. Further evidence exists in the portrait he paints of her. Although Axel tells Helga that he does not understand her, he seems utterly convinced that his picture captures "the true Helga Crane" (88). His contradictory statement confirms that "[i]t is [the] myth of libidinousness that is inscribed on the canvas," not Helga's true countenance (Barnett 588). Helga describes the woman in the portrait as a "disgusting sensual creature with her features," and adds that "anyone with half an eye could see that it wasn't...her" (Larsen 89). She refuses Axel Olsen's subsequent marriage proposal, declaring forcefully that she is "not for sale" and "[doesn't] at all care to be owned" (87).

In her article "Race as Process: Reassessing the 'What Are You?' Encounters of Biracial Individuals," Teresa Williams sheds light on the aforementioned scene:

People's own understanding of their identity is filtered through cumulative racial experiences. . Identity 
formation is complex, interactive, and ever-evolving,

yet racial designations have been created and employed

to simplify, sort, and rank individuals into fixed,

exclusive categories. Placing racial designations is like

trying to frame a moving picture.

This is exactly what Axel Olsen and Denmark society attempt to do by portraying Helga as an "exotic other" and sexually objectifying her based on physical appearance. Particularly in Axel's portrait, the "moving picture" of Helga's identity is rigidly "framed," and as such, captures only a distorted, fantastic representation of her true self. Helga's ardent rejection of this image of herself affirms Larsen's own repudiation of racial/gender stereotyping.

Helga's self-image is, naturally, closely linked to her sexuality. She sees herself as a beautiful, expressive woman, but not as a sexual object open to domination. While Claudia Tate suggests that Helga dislikes Axel's portrait because in it she "recognizes the sexuality" that to this point she has "adamantly rejected," this implies that she, like so many other black women, exhibits a façade of sexual reticence in order to avoid "a racist application of the Jezebel stereotype" (249). Helga's fervid rejection of Axel's image of her does not necessarily demonstrate a fear or repression of sexuality. She is denying that she is a sexual object, not denying her sensuality and desires. After all, earlier chapters clearly show that Helga is aware of her desires. For example, her relationship with former fiance James Vayle incites a sexual "sensation" that "pleased her" inordinately (Larsen 8), and that the sight of Naxos principal Robert Anderson fills her with a similar "mystifying yearning" (20). However, these desires do not mean she is a 
sexual object. When men on the street proposition her, even though she is poor and desperate, Helga is "not...inclined" to stoop to such a level, as "the price of the money [her body and self-respect] [is] too dear" (34). Larsen clearly critiques the notion that one's surface appearance and behavior indicate one's interior by juxtaposing Helga, a sensual and expressive virgin, with the historic tragic mulatta, a sexually active woman (typically out of wedlock) aspiring to purity and modesty. Additionally, Larsen circumvents the tragic mulatta stereotype further as Helga, "a woman of color, a woman of mixed racial ancestry... ultimately rejects [a white male]" to avoid "oppression" (Davis 324-25). In contrast with Child's Rosalie and Xarifa, Stowe's Cassy, and Chesnutt's Rena Walden, who all show a preference for white lovers despite the fact that they are oppressed by them, Helga refuses to be with Axel simply because he is white, as she recognizes that being with him will subjugate her "like the confined fire of a hot furnace" (Larsen 80).

While some critics argue that Helga is sexually repressed to the point of being asexual, several moments in Quicksand denote that Helga is well aware of her attractiveness and sensuality, and that her avoidance of the act of sexual intercourse is a conscious, intelligent choice, not merely a subconscious aversion to the expression of her intimate desires, or a fear of being depicted as "immoral" or "savage." Whereas her tragic mulatta predecessors are consistently portrayed as asexual, repressed women aspiring to complete purity as ordered by the standards of true womanhood, Helga does not shy away from her feelings of sexuality. During her engagement with James Vayle of Naxos, she admits to "a feeling of power" (Larsen 8) when thinking of his need for her. The fact that Larsen describes her sexual excitement as "a sensation amounting 
almost to shame" (8; emphasis added) indicates that the "shame" lies not in the feelings themselves, but in the fulfillment thereof. Helga never admits to feeling guilty about her inner sexual feelings, even when she later has them for a married man. Rather, she acknowledges that the haphazard gratification of such feelings is what she might end up being shamed by. As such, Larsen ambiguously notes that Helga "[shrinks] away from" sexual relations with her fiancé, "subtly aware of possibilities she herself [cannot] predict" (8).

Deborah McDowell contends in her introduction to Quicksand that "Helga is preoccupied with the issue of "legitimacy" and, as such, realizes that "[t]he only condition under which sexuality is not shameless is if it finds sanction in marriage" (xxi). While it is possible that the prospects of having to marry earlier than planned, of bearing an illegitimate child, or feeling "shame" are some of the "possibilities" that keep Helga "pure" during her relationship with Vayle, it is likely, given her obvious complexity, that other concerns plague her as well. First, as Cheryl Wall points out, "[s]he does not consider chastity the supreme virtue the women at Naxos insist it is" (100). Helga, unlike many other women in Quicksand, does not live her life based on what others will think of her. In staunch defiance of the tragic mulatta tradition, Larsen does not allow her character to blend into a wall, or to meekly portray herself as a pillar of piety and purity fresh from the "cult of true womanhood" era just to be in line with white patriarchal standards. Helga admits to "distrusting religion" also, preferring to abide by her own rules for behavior (Larsen 34).

Though she is engaged to James Vayle, Helga says that she "[has] never loved him" (24). Furthermore, after leaving Naxos, she admits that, "even had she remained 
[there], she would never have been married to him" (24). Thus, Helga's avoidance of a sexual relationship with him can also be seen as her conscious desire not to hurt him as her "gay suave scoundrel" of a father had hurt her mother in a moment of "passion" and "blind surrender" (23). Here, Larsen shows Helga drawing on all facets of her past in order to make healthy decisions, an important component of the biracial female identity Larsen and Hurston advocate. More importantly, the implication that Helga's "sexual repression" is only about appearances wrongly ignores the fact that her real desire, according to Marita Golden, is "to fashion a love, an affair, or a marriage based on respect and honor for self and partner" (viii). By presenting Helga as a woman consciously in control of her sexual choices, Larsen critiques fixed racial/gender designations by demonstrating that a woman can be beautiful and sensual without being an object, and can decide to avoid sexual gratification/consummation for a reason other than the fear of being defined negatively by society. As Jacqueline McClendon adds, "Larsen dispels the myth regarding the innate frigidity of the light-skinned female, the alleged opposite of the dark-skinned loose woman, and thereby inveighs against the correlation of values with color or "blood" (267).

Larsen uses Helga's strong sexual desire for Dr. Robert Anderson, principal of Naxos, to subvert the tragic mulatta pattern once again, in that the primary focus of Helga's attention in the novel is a non-white male. Unlike Harper's Iola Leroy, however, whose connection to a black man is deeply invested in her allegiance to the race, Helga's initial attraction to Anderson is purely physical. Of course, Helga was previously engaged to a non-white male, but she did not feel for him the same attraction she feels for Anderson. While Helga never comments on James Vayle's physical appearance, noting 
instead that she was initially attracted to him because of loneliness, she repeatedly makes mention of her mysterious attraction to Robert Anderson's "prominent gray eyes" against his "brown face" (Larsen 50-51). Helga is, above all, fascinated by the contrast of his eye color against his skin color, a combination she deems both "[q]ueer" and "frightening" (20). She sees in his unique physical features the "distinctiveness" that she treasures about herself as a biracial woman, and therefore feels a powerful connection to him.

When Helga initially steps into his office to resign her teaching position at Naxos, the first sight of him catches her mysteriously off-guard:

At his "Miss Crane?" her lips formed for speech, but no sound came. She was aware of inward confusion.

For her the situation seemed charged, unaccountably, with strangeness and something very like hysteria.

An almost overpowering desire to laugh seized her.

The beginnings of Helga's strong infatuation are evident in this passage. Quite unlike James Vayle, who "loathed the idea that [Helga] couldn't manage to win liking and approval," Robert Anderson recognizes and appreciates her difference, telling her that she has "something to give which [is] badly need[ed] in Naxos" (Larsen 7, 21). Because she has explained to him her aversion to the "suppression of individuality" (20), Helga begins to feel from his comment that he, too, recognizes its necessity in a venue that encourages and demands fixed categories and conformity. As he urges her to remain at Naxos, so powerful is her attraction to him that Helga feels "a mystifying yearning" well up inside her, accompanied by an acute "desire to stay, and [even] to come back next 
year" (20). However, her abrupt change of heart is not, as Karen Chandler suggests, the result of her "sexual inhibitions" (37). When Anderson calls her "a lady" (Larsen 21), Helga sees his attempted flattery as a false assumption that her goal in life is to achieve the Victorian ideal of what Helga wryly calls "ladyness," as exemplified through the "humorless, prim, ugly" Naxos dormitory matron Miss MacGooden and Helga's other female colleagues (12). Her departure at that moment is a conscious, intelligent decision not to let her attraction for a man prompt her to do something that goes against her nature.

Moreover, Helga is prompted to leave when Anderson suggests that she is a "lady" merely because of "breeding," or "good stock" (21). She is filled with "turmoil" at his words, because she fears that he does, in fact, see her as someone special only in that she appears to have had the "ideal" upbringing in a "proper" family (21). Larsen's revision of the tragic mulatta convention in this scene is particularly poignant. In contrast with Chesnutt's Rena Walden, who keeps her poor, black ancestry concealed because she believes it will render her "less pure, less innocent, less desirable [and] less worthy to be loved" (Chesnutt 76), Helga rebels against the idea that one's ancestry determines one's value as an individual. She boldly announces her lineage for the first time here, informing Anderson icily that her "father was a gambler who deserted [her] mother, a white immigrant. It is even uncertain that they were married" (21). Helga is open with Anderson because she wants him to see her for who she truly is, not who he thinks she is. More importantly, her defiance of his statement exposes the limitations inherent in the ideology of biological determinism upheld by the tragic mulatta tradition. 
When Helga later encounters Anderson in Harlem, the feelings of excitement come back to her in a mystifying moment of "consternation" (50). Under his "steady gaze," she feels "a strange, ill-defined emotion" welling up within her (50). As George Hutchinson accurately observes, Helga's attraction for Robert Anderson goes beyond lustful desire, in that he "affirm[s] an identity that is "neither black nor white," and "might be able to offer her the sort of understanding and recognition she craves" (553). Helga learns that Anderson, too, left Naxos, as he was "too liberal. . for education as it was inflicted [there]" (Larsen 52). Additionally, she sees him fraternizing comfortably with Audrey Denney, indicating his acceptance of people who defy racial categorization. Larsen notes that "his presence evoke[s]" in Helga a "longing for sympathy and understanding" (50). When he tells her, "You're still seeking for something" (50), she is momentarily frightened, because, although she has longed for someone to connect with and understand her, she is unprepared for such an event to actually happen. As such, Anderson's words ring "painfully true" for Helga (Hutchinson 553).

Anderson's marriage to Anne Grey while Helga is in Copenhagen sets into motion a chain of events that lead to Helga's ultimate "tragedy." His decision to marry Anne does not leave Helga in the position of the classic tragic mulatta, abandoned by her lover because of her unfortunate racial mixture. Anderson never promised himself to Helga, nor did he even admit to loving her, though there are suggestions that he was beginning to have strong feelings toward that end. When Helga loses Anderson, she loses the hope or promise of acceptance and understanding, and as such feels "alone" and "isolated" (Larsen 109). Heretofore he had been the one person who seemed to empathize with her longing to be accepted for who she truly is. The fact that Helga 
succumbs to his advances when he kisses her at Helen Tavenor's party indicates her deep-rooted feelings for him. The "long-hidden...desire" (104) she admits to feeling is not necessarily evidence of sexual repression based on fear of negative social stigma, but evidence of the fact that she has consciously chosen to wait for a man she truly loves, who truly loves her in return as well. This is also a revision of the tragic mulatta pattern. In contrast with Child's Rosalie, for example, who meekly steps aside when her lover marries another woman because "her spirit [is] too pure to form a selfish league with crime" (Child 3), Helga does not adhere to society's notion that sexuality is only "legitimate" within the confines of marriage. Rather, she feels, albeit momentarily, that his kiss is evidence of his feelings for her, which will "legitimize" the consummation of their relationship on her own terms, rather than those of society.

However, as Kimberly Monda asserts, "Helga's desire for recognition from Anderson is...clear in her self-destructive reaction to his rejection" (34). His apology for the kiss that had elicited "riotous and colorful dreams" and "fancies" within her renders her "broken physically" and drenched in "mortification" (Larsen 105, 109). She comes to a painful realization that he is "not the sort of man who would for any reason give up one particle of his own good opinion of himself" (108). Additionally, she recognizes in him her own fear of ostracism and need for belonging, and the fact that he has succumbed to them by marrying Anne rips the hope from Helga's heart. This is the beginning of Helga's downfall. Without the approval and acceptance of Robert Anderson, the one person Helga was counting on to love and care for her, she opts to abandon her quest for self-identification as a biracial female in favor of finding acceptance anywhere she can. 
Karen Chandler sums up the ending of Quicksand as "Helga Crane's sudden fall from the sophisticated, urban black middle class into rural squalor" (25). This glossy assessment, however, suggests that Helga's end, like so many tragic mulattas' before her, is the result of an unavoidable fate. Moreover, it suggests that the problems Helga encounters result merely from her sudden change of geographic and class locations. While it is true that Helga does not have a happy ending, it is not the work of fate; it is the result of her own foolish choices after Robert Anderson's rejection of her gift of loving self- and sexual expression. Defeated by a broken heart and wounded pride, she gives up on her quest for self-actualization and succumbs to the stereotypes and hypocrisy that she had fought for so long to avoid. First, she walks into a church service, where she discards her positive self-image as a biracial female and accepts without protest the branding of "scarlet 'oman" and "pore los' Jezebel" merely because of her "clinging red dress" (Larsen 112). In “'Making Generations' in Jacobs, Larsen, and Hurston: A Genealogy of Black Women's Writing," Patricia Barbeito points out that

[t]hrough these lines, Larsen highlights the different implications of Helga's status as 'lost.' Though not figuratively a 'lost woman,' Helga is literally lost: she is unable to find a place for herself.

Therefore, she ends up in a "tiny Alabama town," bound forever to an unattractive preacher husband she marries in an impetuous moment (Larsen 118). It is interesting here that Helga's assertion of sexual power, first by seducing Reverend Pleasant Green and then by giving to him what she still feels belongs to Robert Anderson as a means of "revenge" (117), ultimately subjugates and rigidifies her. Upon Anderson's 
rejection of her, she has sexual relations with the first man she comes in contact with. She relinquishes control over her body in a daze of "half-hypnotized consciousness" because "nobody" is "there to hold her back" (115). Larsen resists the tragic mulatta stereotype once again in that this man Helga sleeps with and subsequently marries is black. She does have sexual desire for him; in the initial stages of their relationship, Helga yearns for "night," when she will be overtaken by a "medley of feelings" and "anticipation" (120). However, their sexual relationship serves merely as an "anaesthetic satisfaction for her senses" (118). Helga does not experience the "ecstasy" or "onrush of emotion" (105) that she used to feel when only thinking of Dr. Anderson, because she does not really love Reverend Green. As such, any physical feelings she has for him quickly fade into obscurity. Helga, who previously took such pleasure in beauty and attractiveness, now feels "unconquerable aversion" to a man whose "finger-nails [are] always rimmed in black" and who "[fails] to wash his fat body" $(129,121)$. However, she succumbs to a lifetime with him, and the end of the novel finds her weak, sick, and miserably pregnant with "her fifth child" (135).

Marita Golden says of Quicksand's conclusion: "I can't remember any ending to a novel which frightened or warned me more effectively" (viii). What, then, is Larsen's warning? Most critics believe that the author's only point with regards to Helga's seemingly lifelong state of maternity is that marriage and motherhood are confining institutions for all women. However, it is important to focus on Larsen's staunch critique of Helga as well. Helga's "asphyxiation," she notes repeatedly, is "all of her own doing" (Larsen 134). First, she has caved into the confinement of marriage. In contrast with her tragic mulatta ancestors, who insist that their relationships with men be "sanctioned by 
Heaven, [even if] unrecognised on earth" (Child 2) so that they may remain pure and moral true women, Helga ironically deems marriage an "immoral" (134) institution because of the suffering that accompanies it, again indicating her defiance of societal standards.

Furthermore, because she is married, she has also caved into the "oppression" (135) of motherhood. She is forced to endure one childbirth after the other, despite the fact that each one fills her with "hideous agony," because, as Sary Jones, a church lady, informs her matter-of-factly, "et's natu'al fo' a 'oman to hab chilluns" $(129,125)$. Larsen makes another important revision of the tragic mulatta stereotype here, in that motherhood is not, in fact, "natural" for Helga. Whereas Child's "The Quadroons," Stowe's Uncle Tom's Cabin, and Brown's Clotel all employ mulatta protagonists who have "natural" maternal instincts that demonstrate their potential to be "true women," motherhood is actually a debilitating institution for Helga. Although at first she acts as though she loves and is interested in her children, her attitude toward them grows increasingly colder. By the time her fourth child arrives, it is nothing more to her than "a sop of consolation for the suffering and horror through which she had passed" (127). Moreover, Larsen foreshadows that motherhood will eventually lead to Helga's death, as she becomes more and more ill with each pregnancy.

Hence, Helga betrays her goal of a biracial, multiple identity, in favor of assuming a "new status as a preacher's wife" and a mother, believing that this role makes her "a person of relative importance" (118) rather than a lonely, unaccepted individual. Larsen's message in challenging the tragic mulatta here is quintessentially feminist. According to Thadious Davis, Helga's tragic end is not that she "finds marriage and 
motherhood," but that those things "have not actually been the goals of her energy, independence, and intelligence" (276-77). Helga is given the means to be able to determine her destiny; she is not a weak, helpless victim of "melancholy of the blood." Larsen's success in challenging the tragic mulatta lies not in Helga's destination, but in her journey, as, unlike the tragic mulattas of the past, Helga's tragedy is "self-made" (276). 
Subjugation and Self-Validation in Nella Larsen's Passing

While Helga Crane's acceptance of limiting racial/gender categorization constitutes only a small part of Quicksand, Nella Larsen's second novel, Passing (1929), offers a more detailed exploration of the lives of two mulatta women who choose fixed, singular identities for the "sense of security [and] feeling of permanence" (Larsen 187) they appear to offer. Larsen's protagonists, Irene Redfield and Clare Kendry, are not tragic mulattas, because, as Marita Golden notes, "they are driven by the impulse to shape their lives [rather than succumbing to them] even when... careening full tilt toward disaster" (vii). Ironically, Larsen makes the need for the construction of biracial female identity abundantly clear through her depiction of the women's spiral into such "disaster." She critiques the act of "passing" as a means of evading a part of one's racial/cultural heritage by emphasizing its debilitating and ultimately devastating effects on female identity. Furthermore, she shows that "passing," a maneuver primarily utilized in the resistance of marginalization, actually renders women submissive and subjugated. Larsen revises the tragic mulatta tradition in that Clare, who is "passing" permanently as a white woman, attempts to move toward self-validation as a biracial female. However, though such an idea intrigues Irene, Clare's increasingly liminal position simultaneously threatens Irene's artificial, fixed social status, self-image, and even her marriage, culminating in tragedy for both characters.

For biracial people, "fluidly moving about the various boundaries" of racial categories has the potential to "undermine and subvert racial dichotomization" (Williams 
209). However, Irene's and Clare's movements between racial categories do the opposite. It is evident from the beginning of the novel that both Irene and Clare use "passing" as a means of completely escaping black racial identification in favor of embracing a societally constructed standard of "whiteness." The two friends are reacquainted, after a twelve-year separation, in Chicago's Drayton Hotel, where both are posing as white women. Here, Larsen invokes a contrast between Irene and Clare, as the former, a hypocritically altruistic "race woman," says that she is passing only for the sake of convenience, to avoid the "brutal staring sun" of the outdoors (Larsen 146), while the latter openly admits that she is passing permanently as a white woman. However, the women are alike in that whether temporary or permanent, "passing" is a purposefully manipulative and deceitful act for both of them; it is a means of hiding rather than asserting their mixed racial heritages.

During the women's initial encounter, Larsen undermines the notion of racial essentialism that is so prevalent in previous tragic mulatta tales, in that Irene, who professes to be able to "tell the sheep from the goats" (206), cannot recognize her own childhood friend, and immediately believes her to be completely "white" based on her appearance. Furthermore, Larsen uses this scene to begin her critique of the act of "passing." Irene experiences feelings of "anger, scorn, and fear" (150) under Clare's knowing smile. Though she claims she is not overtly passing at this point, she is still unaccustomed to being perceived as a black woman in public spaces. "Never," she notes, "had [anyone] even remotely seemed to suspect that she was a Negro" (150). While she hypocritically adds that she is not "ashamed" of her racial heritage, her discomfort at 
being "found out" suggests otherwise. As E. Franklin Frazier states in Black Bourgeoisie: The Rise of a New Middle-Class in the United States,

The black bourgeoisie [as exemplified through Irene] live largely in a world of make-believe, [and] the masks they wear to play their sorry roles conceal the feelings of inferiority and of insecurity...

While Irene is not a "permanent passer," as is Clare, her social role in the black bourgeoisie, as well as the value she places on status, class, and acceptance by white people indicates that "passing" means more for her than "looking white." She feels that being perceived as white by others increases her worth as a person. For example, although Irene battles feelings of insecurity and fear when she thinks Clare first "suspect[s] her race," her feelings of confidence and self-assurance quickly return when she assures herself that Clare "couldn't prove it" (Larsen 150). Only when she is certain that her "whiteness" cannot be disproved does she feel secure in herself. As Jacqueline McClendon points out, "Larsen postulates that passing is as much a state of mind as a physical act" (269).

However, while Irene dabbles in "passing" only sporadically, it is a way of life for Clare. Raised by her "respectable and authentic" white aunts, she was taught from a young age to deny the "Negro blood" in her veins, lest she fall from favor in the eyes of white society (Larsen 158). Larsen critiques the ideals of "true womanhood" as Clare relates her background information to Irene. While the traditional tragic mulatta would have revered her white aunts as pillars of virtue for their adherence to "the Scriptures, and talks on morals" (159), Clare notes with obvious sarcasm that, "[f]or all their Bibles 
and praying and ranting about honesty...they couldn't forgive the tar-brush" (159), indicating her awareness of their hypocrisy. However, Clare is aware of her own hypocrisy as well, as evidenced in the fact that she marries a white man who has no knowledge of her racial heritage, simply for the benefits of financial provision.

Although Clare asserts that the denial of her biracial status is of "great value" (159) to her in terms of the luxuries it affords her, those luxuries come with a heavy price in terms of her female identity. Because she is forced to deny her racial heritage in order to enjoy the financial and material benefits of marriage, she is simultaneously denied more important benefits, such as sexual fulfillment. Clare openly admits that her marriage is a sexless one. Due to the fact that she "nearly died of terror the whole nine months before [her daughter] Margery was born for fear that she might be dark," Clare is unwilling to run the risk of becoming pregnant with another child who might potentially "turn out dark" and expose her racial roots (168). However, despite her seemingly asexual nature and conformity to white standards, Larsen does not depict Clare as a proponent of "true womanhood" in the tradition of the tragic mulatta. For example, unlike Child's Rosalie, Stowe's Eliza, and Brown's Clotel, who each have daughters that they cherish above all else, Clare appears to be ambivalent toward her own daughter and never expresses the maternal instincts possessed by previous tragic mulattas. She frequently sends Margery away to stay with friends, and later admits to Irene "that being a mother is the cruellest thing in the world" (197). This is an important revision of stereotype. While the historical tragic mulatta is consistently "denied the joys of true domesticity" (Yellin 72) because of her "drops of black blood," Clare rejects those 
supposed "joys," indicating that she craves more than what her limiting racial/gender categorization can offer her.

After Irene and Clare are reunited at the Drayton, Clare invites Irene to her home, along with Gertrude, another woman passing for white. This scene, in which Clare's husband joins them for tea, is perhaps Larsen's most effective argument against "passing." John Bellew, Clare's exceedingly racist husband, is blissfully unaware of his wife's mixed racial background. Accordingly, he believes Irene and Gertrude to be white as well, as it is inconceivable to think that his wife might be associated with members of a "lesser" race. Irene watches in horror as John Bellew nonchalantly refers to his wife as "Nig" because, as he says, "she's gettin' darker and darker" (171). Clare cannot defend herself against his derogatory remarks, because to do so would give away her disguise, so she behaves submissively and "[lays] her hand on his arm with an affectionate little gesture" as he scathingly spits out:

I know you're no nigger. . I draw the line at that.

No niggers in my family. Never have been and

$$
\text { never will be. }
$$

For all that Irene appears to be appalled with John Bellew's domineering opinions and Clare's meek acceptance of them, she too assumes the role of subjugated woman in this scene. The only thing stronger than her "anger and indignation" about being referred to, albeit unknowingly, as one of the "black, scrimy devils" Bellew despises, is her reluctance to admit that she is not, in fact, white (172). Here, Larsen demonstrates, quite clearly, that "passing" requires women to remain "passive, submissive responders" as 
dictated by the code of "true womanhood" (Welter 159). In their attempts to be perceived as white, they simultaneously support racial and gender oppression.

George Kich's "In the Margins of Sex and Race: Difference, Marginality, and Flexibility" analyzes the effects of this oppression:

When [biracial] people alienate themselves from their true selves and their true self-reflections, in order to safely relate to the dominant group. . . [t]he self-oppression that results creates a fog of emptiness, fear, and ambiguity to self. (273; emphasis added)

This is precisely what happens to Clare as a result of her denial of a part of her "true" self. However, in resolute defiance of the tragic mulatta convention, Larsen refuses to allow Clare to remain in this "fog" of "pain, fear, and grief" (Larsen 201). Rather, Larsen advocates the construction of a biracial female identity in that Clare expresses a sudden, urgent desire to reconnect with the once-denounced part of her heritage. In a letter to Irene, she writes desperately:

You can't know how in this pale life of mine I am all the time seeing the bright pictures of that other that I once thought I was glad to be free of. . .It's like an ache, a pain that never ceases. .

Clare's life is "pale" because she is unable to express her multiple identity and is relegated to a bland emulation of "whiteness." Her longing to accept and embrace the "other" part of herself is not only a major revision of the tragic mulatta tradition, but is also, according to Jan Weisman, "an act of self-validation" for biracial individuals, in 
which "otherness is claimed rather than assigned, positive rather than negative" (154). Unlike Harper's Iola Leroy, however, Clare's longing for her "other" self does not necessarily entail a complete separation from whiteness. Rather, her desire to openly move between worlds suggests a longing for multiplicity. However, Clare's desire for multiplicity is not easily attainable, particularly because of the threat her increasingly ambiguous position poses to Irene's fixed, "safe" black bourgeoisie existence (Larsen 196). Clare's liminal position rocks the stability of Irene's social status, self-image, and even her marriage; in essence, she threatens her very life.

Initially, it seems as though Irene, too, is intrigued with the idea of pursuing a biracial identity. She has numerous white friends, with whom she interacts frequently at social gatherings in Harlem. Simultaneously, she is a seemingly dedicated "race woman," in the tradition of Quicksand's Anne Grey, who appears to devote all her time and effort into aiding lower-class Negroes. Furthermore, she occasionally engages in "passing," which indicates her willingness, even eagerness, to be identified with the white race. Nonetheless, Irene's varying racial positions do not indicate the "groundedness...in multiplicity" that characterizes biraciality (Root 204). As previously mentioned, she uses "passing" solely as a means of rejecting her black heritage. This is made particularly evident when she relays the story of John Bellew's defamatory comments to her husband, Brian, and he replies casually, "the man...didn't call you a nigger" (Larsen 184; emphasis added), indicating that, when passing, Irene's "black self" is a completely separate, if not nonexistent, entity.

Also, Irene treasures her position in the black bourgeoisie because it affords her the opportunity to emulate "white" standards, not because of her innate racial pride. She 
considers herself "above" the rest of the black race because of her class position and light skin color, even belittling her maid Zulena by calling her a "creature" due to her dark, "mahogany-coloured" complexion and subservient position (184). Nevertheless, despite Irene's obvious internalization of the superior white/inferior black dichotomy, Larsen does not present her as the classic tragic mulatta. Irene is not a pathetic victim of her "drops of black blood"; rather, she is a woman who schemes, manipulates, and controls in order to maintain the "security" and "permanence" of her comfortable, fixed identity as a race woman (187). Irene fears losing her esteemed social standing and becoming nothing more than "the link between [Clare] and her poorer darker brethren" (185). As such, she attempts to dissuade Clare from entering and exploring Harlem society, by informing her that "it's dangerous" and "you ought not to run such silly risks" (195). However, Irene does not actually see Clare's attending the dance as "dangerous"-it is what such a move symbolizes that causes her to feel "repugnant" at the thought (195).

Clare's expressed longing "to see Negroes, to be with them again, to talk with them, [and] to hear them laugh" (200) prompts her to attend the Negro Welfare League dance, at which time it becomes evident that the "danger" associated with her presence is that it threatens not only Irene's social position, but also her self-image. As Lillian Comas-Diaz points out, "[p]hysical appearance is a central component of female identity" (185). Irene's ubiquitous grooming rituals and self-consciousness regarding her appearance in the novel indicate her attempt to fashion a "white" identity by emulating as closely as possible the standard Victorian ideals of beauty. She consistently covers her "warm olive skin" with "powder" (183), which is symbolic of her desire to, like Clare, wear "an ivory mask" (157) to hide her "blackness." Additionally, Jean Marie Lutes 
asserts in "Making Up Race: Jessie Fauset, Nella Larsen, and the African American Cosmetics Industry," that Irene is rigid about her appearance, "frequently engag[ing] in beauty rituals-looking in the mirror, brushing her hair, [and] powdering her face" in the hope "that her body will not betray her blackness" (98).

On the other hand, Irene views Clare's "loveliness" as "absolute" (Larsen 161), in that she naturally possesses the qualities that Irene works feverishly to attain. Irene's observations of Clare's physical appearance are consistently positive. The "white" aspects of her countenance are noted with admiring imagery, such as when she refers to Clare as "fair and golden, like a sunlit day" (205). Moreover, Irene's assertion that Clare seems to be "a shade too good-looking" to be among Negroes (198) at once attests to her belief that "white" features are infinitely better than "black" ones, and renders her "inferior" next to Clare, thus threatening her carefully constructed self-image. Irene's simultaneous awe and disdain for Clare upon first seeing her dressed up for the Negro Welfare League dance are evident in her "choked exclamation of admiration" (203). Here, Larsen critiques her character's internalization of the problematic binary that upholds "white" features and deems other features ugly by default. Because of her "black curls" and olive skin, Irene, a lovely biracial woman, immediately feels "dowdy and commonplace" next to the "exquisite, golden" Clare (203).

While Clare is, in a sense, entering black society for the first time, her racial position remains one of ambiguity, and as such, she is looked upon as an "exotic other," as was Helga Crane in Copenhagen society. She is described, like a showpiece, as exquisite, golden, fragrant, flaunting, in a stately gown of shining black taffeta, whose 
long, full skirt lay in graceful folds about her slim golden feet; her glistening hair drawn smoothly back into a small twist at the nape of her neck; her eyes sparkling like dark jewels.

Irene contributes to Clare's objectification by remaining secretive when her white friend Hugh Wentworth remarks in wonderment, "I'm trying to find out...the name, status, and race of the blonde beauty out of the fairy-tale" (204-205). While biracial identity theorists advocate "the exploration of an otherness that is empowering and not alienating" (Kich 290) as a vital component of multiplicity, Irene's motivation in objectifying Clare as an "exotic other" is for the opposite reason. Irene feels that by attempting to "stabilize" Clare's identity, she can stabilize her own as well. As Patricia Hill Collins asserts in Black Feminist Thought, "the 'Others'. . .who stand at the margins of society clarify its boundaries [;] by not belonging, [they] emphasize the significance of belonging" (70). Thus, by manipulating Clare into a marginalized position, Irene cements her own "fixed" social/racial position, thereby refuting the historical characterization of the mulatta as the helpless victim of her circumstances.

However, Clare still poses a threat to Irene's marriage, which constitutes the core of her "fixed" position. In "Sneaking Around: Idealized Domesticity, Identity Politics, and Games of Friendship in Nella Larsen's Passing," Frank Hering aptly observes that for Irene, marriage is but a means to "acquiring bourgeois domesticity and respectable upward mobility" (41). Her husband Brian, a wealthy biracial doctor, offers her the security and societal position she craves, but little else. Irene does consider him to be 
"rather handsome," and, like Helga Crane of Quicksand, she focuses primarily on the description of his "copper" skin and "tea-coloured" fingers, indicating that his handsomeness is due to his biracial features (184-186). However, she does not feel the same "onrush of emotion" that Helga feels for Dr. Robert Anderson (105). Theirs is a sexless marriage, as evidenced by the fact that Brian has "his [own] room next to hers" (224), and Irene admits that she has never "wanted or tried for more" in terms of sexual intimacy (235). The fact that Brian refers to sex as "a joke" further indicates that it has become a distant, trivialized aspect of their lives (189). Like Clare, Irene married a man for social status only, and as such, has denied herself of the joys of love, passion, and fulfillment. Though Irene later muses about love, referring to it wistfully as an "exquisite, torturing emotion," there is no evidence of that in her life with Brian (202). While she says that they love each other, it is a decidedly "undemonstrative" love (190).

However, unlike Irene, Clare's resistance of rigid racial/gender categorization affords her the opportunity to be sexually "demonstrative." Larsen subverts the tragic mulatta tradition once more in that Clare, unlike Child's mulattas in "The Quadroons" and Chesnutt's Rena Walden, rejects her white husband and begins to display an obvious attraction for a biracial man, starting with shared smiles, moving on to “dancing...frequently" (204), and, according to Irene's stated suspicions, culminating in a sexual liaison. Clare's attraction for Brian, like Helga Crane's for Robert Anderson, likely extends beyond the physical. While others in Harlem society see her as a racially ambiguous "object of aesthetic pleasure," "mysterious and strange" (209), and a "blank slate" for others to try to "figure out" her race, Brian is fully aware of her life background, as well as the oppressive conditions of her marriage that prompt her to seek 
a biracial female identity. He can offer the acceptance and validation of her biracial self that she craves. Moreover, Clare can sympathize with Brian's disdain for the black bourgeoisie's aspirations toward "whiteness," as well as his desire to "[go] off to Brazil" to escape American racism (187). Irene has exerted all of her energies into resisting Brian's dreams, as they threaten to "disrupt the life which she had so admirably arranged for them" (187). She is so desperate to deny the black part of her racial heritage that she adamantly refuses to move to Brazil, and does not let Brian teach their sons about lynching and the history of racism. Unlike Irene, however, Clare has a growing understanding of the importance of maintaining connections with the past, of being honest with oneself and others, of acknowledging rather than denying oppression, and of seeking to overcome it. Because of her desire to embrace a biracial self-identification, she is able to sympathize and connect with Brian in a way that his wife cannot. This is not to say, however, that sexual attraction is submerged here. Contrarily, Larsen's emphasis on Clare's palpable sexual attraction for Brian is another revision of the tragic mulatta stereotype in that, unlike Harper's Iola Leroy, it has nothing to do with "race allegiance" or "race-building," and everything to do with individual desire and fulfillment, a vital component of the biracial female identity Larsen and Hurston advocate.

Irene's suspicion that Brian and Clare are having an affair poses the biggest threat to her stable position as a race woman. As Kevin K. Gaines asserts in Uplifting the Race: Black Leadership, Politics, and Culture in the Twentieth Century, "marriage, as a sign of monogamous sexual purity, conferred status on black...women... reflecting the extent to which their reputation was under siege" (78). The idea that she might lose Brian, and 
consequently, her marriage and "respectable" reputation, alarms her greatly. While Brian does not admit to sleeping with or even fantasizing about Clare, Irene deduces from the "little straightening motion of his shoulders" that he might be "drawing himself up to receive a blow," as though he has something to hide (Larsen 217). Though "the confusion in her mind [is] like the beating of wings," Irene instinctively feels that "he [has] gone. Down to Clare" (217). This scene of "discovery" is purposefully ambiguous on Larsen's part. As Irene suspects that her marriage, the foundation of her "fixed" identity, is crumbling, she too begins to crumble. Martha Cutter posits that "without her identity as the wife of Brian... Irene has no identity at all" (89). Larsen's imagery reflects this notion, in that Irene's earlier dismissal of Brian in terms of sexuality, passion, and understanding, parallels his dismissal of her. She becomes "no more to him than a pane of glass through which he stare[s]" (Larsen 216).

Reminiscent of Clare's earlier assertion that her life had become "pale" because of her consistent emulation of "whiteness," Irene is now virtually translucent. She becomes a mere shadow of her former self; "her hands were numb, her feet like ice, her heart like a stone weight" (233). As she engages in a robotic performance as a party hostess, giving "repetitions of her smile" amid "manufactured conversations" (219), Larsen critiques "natural" domesticity as outlined in the code of true womanhood. Though Irene feels that this gathering is "so like other tea parties she had had," it is also "unlike any of those others" (219), in that she can no longer determine a place for herself in the social circle. She feels isolated and different, and "[s]he want[s]... to shock people... to make them notice her, to be aware of her suffering" (219). Irene is unsure of what to feel or who to be at this point. As such, her focus turns to Clare, whom she faults 
for her confusion as her "plural identity destabilizes [Irene's] sense of identity" (Cutter 89).

While previous tragic mulattas are consistently portrayed as powerless to control their circumstances, Irene is determined to regain her "safe" position in the black bourgeoisie as Brian's wife, and she will stop at nothing, even violence, to attain it. Initially, it appears that John Bellew will be the one to rid her of Clare's presence forever. With "the roar of [his] voice above all the other noises of the room" (238) during the Freeland's party, Clare's biracial status is revealed to Harlem society. Bellew flattens Clare's multiple identities by cursing her as a "damned dirty nigger" (238) and publicly rejecting her as his wife. However, Clare does not burst into tears or express emotional turmoil of any kind. Larsen notes that she is "as composed... as if the whole structure of her life were not laying in fragments before her" (238), indicating that she has been expecting and awaiting this moment. She "even [has] a faint smile on her...lips, and in her shining eyes" (239) that connote her happiness at the public realization of her biracial identity. Even the gazes of the crowd, full of "curiosity and wonder" (238) rather than anger or disdain, suggest that there will be a positive reception of Clare's true identity. Interestingly, Larsen does not depict Clare as being needful of the absolute acceptance of her biraciality as was Helga Crane. Rather, it appears that this is a cathartic moment for Clare, and the beginning of a new, fulfilling life.

However, Irene is adamant that "she [cannot] have her free" (239), lest Clare's new, fulfilling life include stealing away Irene's husband and social standing, and by implication, her economic security and moral reputation as a race woman. The ending is ambiguous, but Larsen suggests more than subtly that Irene is responsible for Clare's fall 
out the window after her confrontation with John Bellew. Larsen notes that Irene "[is]n't sorry" and exerts her only remaining energies into attempting to "put from her memory the vision of her hand on Clare's arm" (239). However, Irene fails to realize the magnitude of her earlier thought that "[w] $[w$ atever steps she took, something would be crushed" (225). Though Clare's "glorious body [is] mutilated" (240), her death does not end Irene's internal agony.

McClendon notes that "[i]n its strong suggestion of murder, [Passing] revises conventional endings of tragic mulatt[a] and passing tales" (270). Larsen hints that Bellew witnesses Irene's crime before exiting the party. As Irene becomes aware of Bellew's quick disappearance, she thinks wildly: "Not that! Oh, not that!" (242), which indicates her knowledge that someone-a white man, no less-will always be aware of what she has done and what she is capable of, and will, in essence, continue to have power over her. It is evident that Irene's problems are far from over. With the weight of guilt, despair, and "stark craven fear" (241) on her shoulders, Irene succumbs to a "great heaviness that submerge[s] and drown[s] her" (242). The "great heaviness" is symbolic here; in essence, by trying to maintain a singular, exclusive racial identity, Irene has made herself vulnerable to further oppression. Although Irene does not die at the end of the novel, her tragedy parallels Clare's. Because she has eliminated Clare in order to maintain her fixed, stable position in black bourgeoisie society, she subjects herself to a lifetime of miserable subjugation as a woman.

Finally, Irene's murder of Clare thwarts the latter's ability to assert a positive and permanent identity as a biracial female. However, not all the blame can be placed on Irene. While Clare's goal of a multiple identity was developing, it had not yet been 
out the window after her confrontation with John Bellew. Larsen notes that Irene "[is]n't sorry" and exerts her only remaining energies into attempting to "put from her memory the vision of her hand on Clare's arm" (239). However, Irene fails to realize the magnitude of her earlier thought that "[w] hatever steps she took, something would be crushed" (225). Though Clare's "glorious body [is] mutilated" (240), her death does not end Irene's internal agony.

McClendon notes that "[i]n its strong suggestion of murder, [Passing] revises conventional endings of tragic mulatt[a] and passing tales" (270). Larsen hints that Bellew witnesses Irene's crime before exiting the party. As Irene becomes aware of Bellew's quick disappearance, she thinks wildly: "Not that! Oh, not that!" (242), which indicates her knowledge that someone-a white man, no less-will always be aware of what she has done and what she is capable of, and will, in essence, continue to have power over her. It is evident that Irene's problems are far from over. With the weight of guilt, despair, and "stark craven fear" (241) on her shoulders, Irene succumbs to a "great heaviness that submerge[s] and drown[s] her" (242). The "great heaviness" is symbolic here; in essence, by trying to maintain a singular, exclusive racial identity, Irene has made herself vulnerable to further oppression. Although Irene does not die at the end of the novel, her tragedy parallels Clare's. Because she has eliminated Clare in order to maintain her fixed, stable position in black bourgeoisie society, she subjects herself to a lifetime of miserable subjugation as a woman.

Finally, Irene's murder of Clare thwarts the latter's ability to assert a positive and permanent identity as a biracial female. However, not all the blame can be placed on Irene. While Clare's goal of a multiple identity was developing, it had not yet been 
realized at the time of her death. By purposely deceiving her husband, first by disavowing her racial heritage and next by "sneaking" into Harlem society functions, Clare sets herself up for her tragic downfall. According to Maria Root, "for the biracial person, acceptance and articulation of one's true self is vital for empowerment" (34). Clare accepts her biraciality, but does not articulate it to her husband, thereby rendering her powerless to control the scene he makes at the Freeland's party, which ultimately leads to her demise. Hence, Larsen presents Clare as a promising, yet unrealized, site for biracial potential.

In Passing, Larsen advocates the need for the construction of a biracial female identity through her depiction of mulatta characters who shape their own destinies, no matter how tragic they are. 
The Realization of Biracial Female Identity in Zora Neale Hurston's Their Eyes Were Watching God

Critics have consistently analyzed Zora Neale Hurston's Their Eyes Were Watching God (1937) as a "prototypical Black novel" (Awkward 6). Additionally, because of her situation within an all-black community throughout the novel, the biracial status of Janie Crawford, Hurston's protagonist, is often ignored altogether in scholarship. However, in order to view the novel as a response to the tragic mulatta tradition, Janie's biraciality cannot be dismissed as irrelevant. On the contrary, she clearly embodies the biracial female identity that Larsen's Helga Crane, Irene Redfield, and Clare Kendry aspire to but never attain. Through Janie's struggle for selfactualization, Hurston revises constructions of black female sexuality instigated and upheld by the tragic mulatta convention, and posits multiplicity as opposed to black essentialism. Moreover, Janie resists all forms of limiting racial/gender categorization and confinement, defying the historical mandates of "true womanhood" by deciding for herself "whut a woman oughta be and to do" (Hurston 16).

Perhaps one of the most important subversions of the tragic mulatta stereotype is in Janie's initial "self-discovery" scene. Janie, who was raised by her "Nanny" and spent the majority of her younger years in the backyard of Nanny's white employers' home, is not even aware that she is in any way different from other children until she identifies herself in a photograph at age six and humorously announces, "Ah'm colored!" (9). This 
scene is a startling parallel to the ubiquitous "element of reversal" in previous tragic mulatta tales, in which the "sudden awareness" of her mixed racial heritage "precipitates the fall of the helpless young female" (Zanger 67). However, unlike Cassy in Stowe's Uncle Tom's Cabin, whose discovery renders her a "lost soul" (Stowe 376), or Harper's Iola Leroy, who experiences feelings of "intense horror and agony" when she is "told the story" of her biracial background (Harper 114), Janie's "sudden discovery" of her mixed racial heritage does not render her miserable, tormented, and eternally confused. She is not suddenly aware of inferiority or cursed with insecurity as a result of this revelation. According to Maria Root, "self-labeling is empowerment" for biracial persons, because "[i]t is a proclamation of existence" (13). Through her surprised exclamation, Janie labels herself "colored" and simply accepts that as a part of who she is, without remorse.

Furthermore, as Hurston notes in her autobiography, Dust Tracks on a Road,

Light came to me when I realized I did not have to consider any racial group as a whole. God made [people] duck by duck and that was the only way I could see them. I learned that skins were no measure of what was inside people.

In the tradition of her creator, Janie does not see skin color as a determiner of personality, value, or destiny. Unlike Nanny, whose opinions are molded by the history of oppressive slavery, Janie feels the need to create her own definitions and question traditional boundaries. For example, perhaps the most frequently cited line from Their Eyes is Nanny's admonition to Janie that "[d]e nigger woman is de mule uh de world so fur as Ah can see" (Hurston 14). Frequently omitted in much criticism, however, is Nanny's 
next sentence, which is "Ah been prayin' fuh it tuh be different wid you" (14). It is evident that Janie pays closer attention to the second sentence, as she attempts throughout the novel to evade being categorized, either as a mule or anything else, because of her skin color or gender. Moreover, while Nanny contends that "us colored folks is branches without roots" (16), Janie asserts that she "[sees] her life like a great tree in leaf" (8). Janie's "roots" are the lessons learned and stories told that make up her cultural identity, not a set of fixed ideas about racial/gender determinism.

Another effective way Hurston defies the tragic mulatta tradition where Janie is concerned is in the fact that the beginning of the novel is actually the end. The story opens with Janie's return to the all-black town of Eatonville, Florida, at which time she shares the details of her years of self-discovery with her best friend, Pheoby Watson. What makes this reversal so poignant is the fact that we know Janie has survivedHurston leaves no room for doubt that Janie is strong, capable, and self-sufficient, and that her story is one worth telling. As Pearlie M. Peters states, "the voices of assertive women are crucial to their own survival" (294). The fact that the novel is actually Janie's own oral story emphasizes her desire to connect with, learn from, and survive the past. She refuses to be a victim of her circumstances like the tragic mulattas of yesteryear.

Hurston evokes the tragic mulatta image in the first chapter of the novel by emphasizing Janie's "great rope of black hair swinging to her waist and unraveling in the wind like a plume" (Hurston 2), making her character's biracial status immediately evident. However, she revises the tradition of lavishing mulatta characters with descriptions of stunning beauty in that there is no mention of Janie's light "coffee-andcream" complexion (140) until much later. More importantly, Janie's hair represents 
something other than her mixed racial heritage; it is also metaphorically linked to her sexuality throughout the novel. This is also a major revision of the tragic mulatta tradition. Hurston does not highlight Janie's luxurious "hair swingin' down her back" (2) as a means of garnering sympathy for her "near-white" character, but rather, uses that very description to symbolize her sexual freedom, in defiance of the "purity" requirement of true womanhood. Furthermore, Janie's "firm buttocks" and "pugnacious breasts trying to bore holes in her shirt" (2) are not presented as negative qualities, but are met with admiration, particularly by Pheoby, who tells her, "you sho looks good" and notes that "[e]ven wid dem overhalls on, you shows yo' womanhood" (4). In this scene, by positively associating Janie's sexualized physical features with "womanhood" rather than lewdness, Hurston revises historical constructions of black female sexuality.

Moreover, Janie's expressive and poetic sexual nature is, perhaps, her defining characteristic as the "new and improved" mulatta figure. In stark contrast with Helga Crane and Irene Redfield, Janie never feels shame or repression of sexual pleasure. There are no worries about objectification or "jezebel" stereotypes in this novel. Hurston defies malignant stereotypes regarding black female sexuality by allowing Janie to be fully sexually expressive, as evidenced in the imagery-laden scene in which a pear tree is being pollinated by bees, a magnificent and sensitive rendering, symbolic of sixteenyear-old Janie's sexual awakening:

She was stretched on her back beneath the pear tree soaking in the alto chant of the visiting bees, the gold of the sun and the panting breath of the breeze when the inaudible voice of it all came to her. She saw a dust- 
bearing bee sink into the sanctum of a bloom; the thousand sister-calyxes arch to meet the love embrace and the ecstatic shiver of the tree from root to tiniest branch creaming in every blossom and frothing with delight. So this was a marriage! She had been summoned to behold a revelation. Then Janie felt a pain remorseless sweet that left her limp and languid.

(Hurston 11)

The nature imagery in this scene is evocative of Hurston's desire to show. sexuality as a normal and natural part of femaleness, regardless of race. As Carol Batker contends in “'Love me like I like to be': The Sexual Politics of Hurston's Their Eyes Were Watching God, the Classic Blues, and the Black Women's Club Movement," this novel "collapses the dichotomy between... respectability and desire, in order to position Janie as sexual but not libidinous" (203). Janie is not the classic tragic mulatta who ascribes to the mandate of "true womanhood" that suggests any expression of sexuality beyond "bestow[ing] her greatest treasure upon her husband" renders her a "[f]allen woman," "unnatural and unfeminine" (Welter 154).

Furthermore, Janie's reference to the above scene as "a marriage" (Hurston 11) does not indicate her conformity to the ideal that sexuality is only legitimate in the bonds of matrimony. Rather, it indicates her belief that marriage should not be a debilitating, confining institution for women, but should instead be a means for the celebration of sexual expression. Janie's idealization of marriage is another revision of the tragic mulatta tradition. For example, unlike Child's protagonists, Rosalie and Xarifa, who 
view marriage merely as a required and necessary aspect of true womanhood, Janie views it as a potential site for sexual happiness and fulfillment. Hence, the blossoming pear tree becomes a controlling image throughout Their Eyes Were Watching God, because it represents the beauty and fulfillment that Janie seeks in terms of her love relationships.

Janie's three marriages throughout the novel represent different stages in her quest for identity as a biracial female. Her first husband, Logan Killicks, is Nanny's choice for her, in order to "marry her off decent like" and ensure her social acceptance and safety (13). Although Janie brands him an "ole skullhead in de grave yard" and feels that he "[desecrates] the pear tree" $(13,14)$, she marries him for Nanny's sake, hoping that "marriage [will] compel love like the sun the day" (21). Reminiscent of Helga Crane's assumption about matrimony to James Vayle, Janie believes that "she [will] love Logan after they [are] married" because "husbands and wives always loved each other, and that was what marriage meant" (21).

In the tradition of Helga Crane once again, however, Janie's dreams of sexual excitement, attraction, and love are thwarted by the decided grotesqueness of her husband's physical appearance. He is not at all the tangible embodiment of her visually alluring fantasies. Just as Helga was eventually repulsed by Reverend Pleasant Green's "finger-nails...rimmed with black" and "fat [unwashed] body" (Larsen 121), Janie complains to Nanny that Logan's "belly is too big," "his toe-nails look lak mule foots," and she would "ruther be shot wid tacks than tuh turn over in de bed and stir up de air whilst he is in dere" (Hurston 24). Additionally, he has "ceased to wonder at her long black hair and finger it" (27). As Janie's hair is closely linked to her sexuality throughout the novel, his avoidance of it implies an absence of fulfilling sexuality in the 
marriage. What makes her cry bitterly, though, is the fact that he "don't even never mention nothin' pretty" (24). The poetry of which Janie dreamed does not exist anymore; "her husband [has] stopped talking in rhymes to her" (26). Ultimately, Janie cannot separate aesthetic appeal from sexual desire as Helga does, because she wishes to stay true to her inner longing for beauty and fulfillment. Hurston revises the tragic mulatta tradition here, in that Janie follows her own wishes and her own vision of sexual happiness rather than succumbing to a lifetime of confinement with someone she neither feels attraction for nor loves.

Through Janie's increasing dissatisfaction with her marriage to Logan, Hurston harshly critiques the notion that the cardinal virtues of "submissiveness and domesticity," as outlined in the code of true womanhood, inevitably lead to "happiness and power" (Welter 152). To Nanny, Logan represents "protection" and "uh prop [for Janie] to lean on" (23), but for Janie, he represents domination. In "Crayon Enlargements of Life": Zora Neale Hurston's Their Eyes Were Watching God as Autobiography," Nellie McKay explains that "Nanny's justification of the young girl's marriage to the aging but financially secure Logan Killicks for safety and protection from other men condones the patriarchal oppression of women" (59). Nanny, who has lived under the bonds of physical slavery, feels that marriage is a safe option for her granddaughter, although it is still, for Janie, a form of slavery. Janie's earlier complaint to Nanny, "Ah wants to want him sometimes. Ah don't want him to do all de wantin" (Hurston 23) indicates that submissiveness does not make her happy at all. She clearly desires equal partnership as well as her own personal and sexual expression and satisfaction. She does not have these things with Logan, and ultimately becomes restless and dissatisfied. When she expresses 
her feelings of confinement to her husband, he comments dryly, "[y]ou think youse white folks by de way you act," then proceeds to inform her, "[y]ou ain't got no particular place. It's wherever Ah need yuh" (30-31). His response not only reinforces his dominance and her subservience, but also implies that Janie, because she is not completely white, has no right to express her opinions or rebel against her designated "place." However, Janie asserts a biracial identity here in her adamant refusal to accept limiting categorization as "de mule uh de world" (14).

The fact that Janie chooses to leave her oppressive marriage to Logan Killicks indicates her defiance of prescribed racial/gender roles, as well as her belief that autonomy is not reserved for "white folks" only (32). Furthermore, as she later tells Pheoby, "Ah done lived Grandma's way, now Ah means tuh live mine" (114). Because her relationship with Logan does not offer her the beauty, fulfillment, or "flower dust and springtime" (32) she craves, she exits the gate of their house for good, swathed in "sudden newness and change" (31). Interestingly, Janie's journey begins where Helga Crane's ends, as Janie refuses to be a submissive, eternally "knocked up" (22) wife like her literary predecessor. She will not submit to the notion that the only place for her as a woman is in the shadow of male superiority. As she walks down the road after leaving Logan, the "morning... air [feels] like a new dress" (32), which is symbolic of the shedding of her former self and donning of a new self, unrestricted by essentialized notions of race and womanhood that forced her into the marriage to begin with. Janie is now liberated, and prepared to formulate a healthy identity as a biracial female.

Janie's next husband, Joe ("Jody") Starks, is a "cityfied, stylish dressed man with his hat set at an angle that didn't belong in these parts," and therefore decidedly more 
appealing to Janie than Logan Killicks. Furthermore, like Helga Crane and Irene Redfield, Janie is attracted to the "seal-brown color" (27) of Joe's skin, in defiance of the tragic mulatta pattern. He is instrumental in her decision to leave Logan, as he treats her kindly, infantilizes her by calling her a "pretty doll-baby," and recognizes in her a youthful craving for "sugar-tits" $(29,28)$. Although Janie is unsure as to whether he represents the poetry and beauty she yearns for, he does stand for "change and chance" (29) and an escape from a limiting existence, just as Copenhagen represented a "new life" for Helga Crane (Larsen 67). Furthermore, he appears to have every intention of treating her "lak a lady" (Hurston 31). Janie believes that she has found in Joe an equal partner, as he assures her that while she may have been expected to work "behind a plow" at Logan's behest, she "ain't got no mo' business wid uh plow than uh hog is got wid uh holiday" (29). He is waiting for her when she leaves Logan, and they are "married .. before sundown" (33) that same day. This does not, however, indicate Janie's desire to adhere to the virtues of true womanhood. For example, unlike Child's tragic mulattas, Janie's marriage to Joe does not demonstrate her desire to be "pure" and "pious." Contrarily, their hasty elopement indicates her rebellion against the ideals of true womanhood, in that she completely disregards the fact that she is already married to Logan, in favor of pursuing satisfaction and happiness with Joe.

However, she quickly learns that the role Joe has in mind for her is not much healthier than the one Logan expected her to assume. Janie's life as the wife of Joe Starks, the ambitious mayor of the first all-black town of Eatonville, places her in the tradition of the black bourgeoisie tragic mulatta. As Joe gains affluence and power in the town, they both become members of middle-class society, in contrast with others in 
working-class Eatonville. Joe informs her that she is the "bell-cow" amid the "gang" of townswomen, and dresses Janie in "wine-colored red" with "silken ruffles" while the other women don "calico" and "headrag[s]" (41). Janie quickly discovers, however, that she is not much more to him than an ornament he can utilize to further his social status. Like Helga Crane in Copenhagen, Janie is put on display like a showpiece of essential blackness. One man's description of her as comparable to "de queen uh England" (42) not only highlights her ostentatious appearance, but also her noticeably light skin color. As Joe introduces her to the townspeople in his store, Janie stands by his side, required to assume an artificial role as a silent, submissive accessory because Joe does not "mean for nobody else's wife to rank with her" (41).

Further evidence of this is when Janie is asked to give a speech after Joe's mayoral election, and Joe informs the public witheringly that Janie's "place is in de home," not "taking the floor. . speech-makin"" (43). Although Janie is quite intelligent and "a born orator" (58), Joe denies her the right to use her talents. However, unlike the tragic mulattas of the past who believed that "[a] wife who [willingly] submerged her own talents...for her husband was... a true woman" (Welter 160), Janie resents Joe's demands; they leave her "feeling cold" and "want[ing] to fight about it" (Hurston 43, 57). His assertion that he "never married her for nothin' lak dat" breathes new meaning into the promise he made during their brief courtship that, with him, she would "live lak [she] oughta" $(29,30,43)$. Toni Flores notes that "Janie, as Mrs. Mayor, is to be not only under his control but also the very symbol of his control and position" (122). Janie's own perception of how a woman "oughta" live is brutally rebuffed by Joe's dominance, and this revelation takes "the bloom off of" her future hopes and dreams (Hurston 43). 
Because Joe confines her to an emulation of white standards, Janie has her moments of bland ambiguity, reminiscent of Clare Kendry's behavior in the presence of John Bellew. As her husband becomes increasingly more controlling, Janie's vibrancy and individuality are suppressed. She begins to feel less important and less capable as a woman under his demands and admonitions. When Joe tells her he wants her to look after the store, Janie replies, "Oh, Jody, Ah can't do nothin' wid no store lessen youse there" (Hurston 43). Furthermore, out of jealousy, "he [orders] Janie to tie up her hair" (55), heretofore her crowning glory and a representation of her sexuality, so that men will not gaze at it. She is denied the right to speech, opinion, feeling, and self-respect as a woman.

However, Hurston does not allow her character to fall into tragic obscurity. When Joe informs her that "[s]omebody got to think for women...I god, they sho don't think none theirselves" (71), Janie finally decides to think for herself and lash out at him for years of mental abuse with her bold declaration:

Ah'm woman every inch of me, and Ah

know it. Dat's uh whole lot more'n you

kin say. . .Humph!. . When you pull

down yo' britches, you look lak de change

uh life.

Anita M. Vickers posits that Janie's emasculating insult serves only as a means through which she can "rebel against the oppressive" (307). While this is certainly true, her words carry a deeper meaning as well. Through her outburst, Janie refutes the notion that a "true woman" must have "a spirit of obedience and submission" (Welter 159). By 
simultaneously asserting herself and affirming that she is still "every inch" a woman, Janie completely defies the tragic mulatta tradition. Unlike Child's Rosalie, Xarifa, and Rosa, Janie does not believe that she must be a silent, helpless victim of patriarchal abuse (whether verbal or physical) in order to also be a "true woman." Moreover, unlike Stowe's Cassy, who, despite a defiant attitude, still suffers from the "inability to control [her] own fate" (Berzon 104), Janie's rebellious outburst serves as a means of taking command over her life. Hurston virtually reconstructs the definition of "true womanhood" in this scene, suggesting that it has nothing to do with submission, obedience and/or silence, and everything to do with having the confidence to assert oneself and make autonomous decisions. Of course, Joe "realize[s]... Janie had robbed him of his illusion of irresistible maleness that all men cherish" and he "[strikes] Janie with all his might" (Hurston 79-80) in an attempt to re-assert his power over her. However, his behavior following her comment does not force Janie into submission; rather, she becomes aware of the power of her own voice, of her opinions. By refusing to speak up for herself to this point, she has reinforced Joe's feelings of masculine superiority. Like Irene Redfield and Clare Kendry in the presence of John Bellew, Janie realizes that her silence around Joe Starks as a result of his insistence that she mimic "whiteness" has, in effect, reinforced her own subservience as well.

While Janie does "[tear] off the kerchief from her head and let down her plentiful hair" in a symbolic act of freedom after death's "icy sword. . .cut[s] off [Joe's] breath," she also takes time to reflect on his life in tender, pitiful remembrance (87). Her assertion that "sittin' in de rulin' chair is been hard on Jody" (87) reveals her growing 
awareness of the debilitating effects of prescribed gender/racial roles on those who accept and embody them. Joe's dominance has not only hurt her, but him as well.

At his funeral, Janie sits amid the crowd of mourners with a "starched and ironed" face (88). Hurston's imagery of Janie's "veil" here provides an interesting contrast to the "masks" worn by Larsen's protagonists in Passing. Whereas Clare Kendry and Irene Redfield assumed false exteriors to suppress/conceal/eliminate their true identities, Janie assumes a façade that protects/nurtures her true identity. Out of respect for Joe and his social role, she assumes the role of submissive, mourning wife. However, "[i]nside the expensive black folds [are] resurrection and life" (88). She distances herself from mourning and "[w]eeping and wailing" because she does not want to allow those "false" elements to pervade the "calm" she feels at coming to terms, once again, with who she truly is (88). Further evidence of her desire to break free of a life of fixed roles, falseness, and hypocrisy, is in her blunt declaration to Pheoby that "mourning oughtn't tuh last no longer'n grief" (93).

Janie's relationship with her third husband, the youthful Vergible "Tea Cake" Woods, fulfills her desire for a union based on mutual respect, equality, and passion, rather than domination. Their relationship also represents her recovered sexual freedom, which is a key element in Hurston's revision of the tragic mulatta tradition. As Maria J. Racine asserts in "Voice and Interiority in Zora Neale Hurston's Their Eyes Were Watching God," "Janie chooses Tea Cake Woods because she is ready for him. Emotionally and physically, Tea Cake takes Janie back to... her initial recognition of love and passion" (288). Reminiscent of Helga Crane's intense feelings for Dr. Robert Anderson, Janie comes alive in Tea Cake's presence, experiencing "little thrills" at the 
sight of his "full, lazy eyes with the lashes curling sharply away like drawn scimitars" (96). Janie's description of him indicates that he has indeed brought the lyrical language of love back into her life:

He looked like the love thoughts of women.

He could be a bee to a blossom-a pear tree

blossom in the spring. He seemed to be crushing

scent out of the world with his footsteps.

Crushing aromatic herbs with every step he took.

Spices hung about him. He was a glance from

God.

He also pays attention to Janie's hair, which is once again unrestrained, symbolic of her sexual self. He combs it for her, calling it "pretty" and asserting that "[i]t feels jus' lak underneath uh dove's wing next to mah face" (103). Here, Hurston revises the tragic mulatta tradition in that Janie's sexual relationship with Tea Cake begins before their marital vows are spoken. Moreover, sexuality in this instance neither objectifies nor oppresses her. Again, it is displayed as a natural part of a woman's life, not something that renders her a "fallen angel" (Welter 155).

Hurston further revises the tragic mulatta convention in that Janie demands respect and fidelity from Tea Cake. In stark contrast with Child's protagonists in "The Quadroons" and "Slavery's Pleasant Homes," who are "powerless to command [their husbands'/lovers'] exclusive sexual attention" (Yellin 73), Janie refuses to be used as a sexual object or disrespected by Tea Cake. Hurston devotes an entire chapter to a situation in which Janie becomes "snappish" because a "chunky girl" named Nunkie 
begins to make sexual advances toward Tea Cake, and he "didn't seem to be able to fend her off as promptly as Janie thought he ought to" (Hurston 136). However, rather than stewing privately and accepting the situation as part of an unavoidable fate that accompanies her "drops of black blood," Janie "[acts] on feelings" and confronts them both "in a cold rage," even going so far as "to seize Nunkie" (137). She does not become a submissive victim like Child's tragic mulattas, particularly Rosalie, who makes "a strong effort at composure" when discovering her lover's affair, in order to remain submissive and of "a pure mind" as ordered by the code of true womanhood (Child 3 ). Instead, Janie vehemently insists on Tea Cake's faithfulness and devotion to her alone. Her embodiment of a biracial female identity is made evident here, in that she simultaneously rejects the ideals of Victorian true womanhood and resists stereotypical objectification, by demanding that her gift of sexual expression be respected and nurtured rather than cast aside and/or exploited.

Janie also seeks equality in her relationship with Tea Cake. Unlike Joe Starks, Tea Cake recognizes and appreciates Janie's intelligence, noting admiringly, "you got good meat on yo' head" (96). With him, she also enjoys many of the things she never experienced while married to Joe: checkers, fishing, movies, baseball games, hunting, even learning to drive. The town of Eatonville, however, begins to speak ill of their relationship, as Janie is still supposed to be in mourning after only nine months of widowhood, not flaunting herself about wearing "blue" and "pink linen" (110). Hurston invokes a critique of imposed bourgeois values here with Pheoby's admonition to Janie that it is odd for her to engage in such activities, seeing as she used to "class off" (112). Janie replies that Joe is the one who "classed [her] off" and then proceeds to announce 
her plans to marry Tea Cake, thus demonstrating her ambivalence toward race, class status, or mobility. Unlike Larsen's Irene Redfield and Clare Kendry, Janie desires love, partnership, and happiness, not a fixed place on the social ladder. This is also evident in that she and Tea Cake eventually move from Eatonville to live "on the muck" in the Everglades, and Janie is even more happy amid "[p]eople ugly from ignorance and broken from being poor" than she was as the wife of Eatonville's mayor (131).

Janie's change of venue from Eatonville to "the muck" is consistently analyzed by critics as a plunge into "essential blackness," which is supposedly the core of her identity. However, when viewing Janie as a biracial character crafted in response to the tragic mulatta tradition, it is necessary to view her affinity for the Everglades community in more complex terms. Although she has rejected the emulation of white standards as a way of life in Eatonville, this does not necessarily mean that she wants to embrace an essential black identity. After all, Janie has resisted all forms of racial/gender essentialism to this point in the novel. While critics emphasize Janie's situation within a wholly black community throughout the novel, it is important to note that "[w] ho the racially mixed person chooses to befriend, [live with], and particularly love, does not necessarily declare [the totality of] his or her racial identity" (Root 13). Unlike Larsen's Helga Crane, whose entrance into Pleasant Green's rural Alabama community actually does represent a plunge into essential blackness, Janie does not conform to any limiting stereotypes or system of prescribed ideals.

Furthermore, the community on the muck is clearly ethnically diverse; to collectively label its members as "essentially black" wrongly dismisses Hurston's effort to create a unique conglomeration of characters that have come "from east, west, north, 
and south" (Hurston 131). Janie's relationships with the "mingled people" (Hurston 141) on the muck indicate her attraction to and desire for multiplicity, not racial essentialism. Her "strange eyes" eagerly drink in the "big and new" community, and she feels a compelling desire to "look around and see people and things she hadn't noticed" previously $(129,139)$. Reminiscent of Helga Crane and Clare Kendry in their initial forays into Harlem society, Janie is fascinated by the variety of people around her on the muck. However, although it is referred to consistently in criticism as an "AfricanAmerican community," black Americans constitute only one aspect of its variety. Janie is attracted to "the subtle but compelling rhythms of the Bahaman drummers [and their] dances," for which "she and Tea Cake [are] on hand every night" (139). They quickly befriend the "Saws," as they are called, and even begin "to hold dances night after night... behind Tea Cake's house" (154). Janie relishes the exciting practices of this previously unknown culture; her behavior here is reminiscent of Audrey Denney's in Harlem, in that she enjoys and appreciates the multifaceted culture around her while simultaneously refusing to be racially categorized. Janie is also fascinated with the band of Seminole Indians who have passed through "several times in the 'Glades, in twos and threes, with "[t]he men walking in front and the laden, stolid women following them like burros" (154). Hurston further highlights the importance of the diverse community in that the Indians are ultimately responsible for the survival of many people on the muck, by warning them well in advance of an impending destructive hurricane.

Moreover, Janie becomes "visiting friends" with another mulatta character on the muck, Mrs. Turner, "a milky sort of woman" (139), whom Hurston employs to show Janie's healthy adjustment as a biracial female by contrast: 
Mrs. Turner's shape and features were entirely approved by Mrs. Turner. Her nose was slightly pointed and she was proud. Her thin lips were an ever delight to her eyes...To her way of thinking all these things set her apart from Negroes.

Mrs. Turner smugly asserts that because she has "white folks' features," she should not be "lumped in wid all de [black people]" (142). She befriends Janie because of her light "coffee-and-cream complexion and her luxurious hair" (140), holding her in the highest regard because she looks even "more white folkish than herself" (144). Furthermore, Hurston notes that Mrs. Turner "didn't cling to Janie Woods the woman" but only "paid homage to Janie's Caucasian characteristics" (145), indicating her critique of the notion that physical features have anything to do with "true" womanhood.

While Mrs. Turner would like to believe that she is alone because she is better than the "black niggers" on the muck (141), her life is one of isolation because of her disavowal of the cultural identity that exists all around her. Her refusal to acknowledge her black heritage leaves her bitter and unfulfilled. Hurston demonstrates the necessity for the construction of a biracial female identity in this scene, beginning with Janie's emphatic response to Mrs. Turner's suggestion that mulattos should form their own class: "Us can't do it. We'se a mingled people and all of us got black kinfolks as well as yaller kinfolks" (141). Biracial identity theorists harshly critique the formation of singular, marginal categories that "perpetuate 'us' versus 'them' schisms and antagonisms" rather than fostering "connections and bridges [and] broadening one's worldview" through 
interactions with all people (Root 13). Janie's resolute defiance of Mrs. Turner's suggestion about "classing off" indicates her resistance of the idea that people should be grouped together based on skin color or appearance, and highlights Hurston's argument for multiplicity as opposed to essentialism.

Mrs. Turner's assertion that she cannot forgive Janie "for marrying a man as dark as Tea Cake" (Hurston 140) prompts Janie to discuss her reasons for being with him. Hurston uses this scene to refute the tragic mulatta stereotype once again. Unlike Harper's Iola Leroy, Janie does not see marriage to a black man as a form of "race allegiance." In fact, there is no mention of Tea Cake's skin color in the text until Mrs. Turner rudely alludes to it. Janie does not even respond to Mrs. Turner's comments about Tea Cake being too dark "[t]uh git hold of uh woman lak [her]" (140). Instead, she simply declares, "Ah loves "im" as her reason for marrying him, discarding the notion that her feelings have anything to do with his race. Furthermore, unlike Helga Crane's loveless marriage to Pleasant Green, Janie's relationship with Tea Cake is not marked by racial/gender oppression and confinement. Tea Cake does not treat her like "de mule uh de world" as Logan did, nor does he publicly objectify her as a glittery representation of essential blackness as Joe did. Janie is free to embrace the multiplicity of her identity with Tea Cake, in that he, too, does not believe in racial essentialism. For example, upon discovering that Mrs. Turner "hate[s] black folks," Tea Cake suggests that they discontinue their patronage of her "eatin' place," noting that they "kin go tuh dat white man's place and get good treatment" instead (143). Moreover, his disgusted remark to Mrs. Turner that she should not "make God look so foolish-findin' fault wid everything 
He made" (145) parallels Janie's acceptance of and associations with all people, regardless of race.

Thus, Janie finds happiness in her life with Tea Cake because he is as accepting of multiplicity as is she, though their relationship is also flawed in a number of ways. In "The Tapestry of Living: A Journey of Self-Discovery in Hurston's Their Eyes Were Watching God," Janice L. Knudsen says that, although Tea Cake is not perfect (he steals from Janie and also beats her), "Tea Cake and Janie, mirroring approval and affirmation of each other... have a healthy relationship" nonetheless (226). While it is true that Tea Cake is decidedly better than Joe Starks as a husband, he is not the be-all and end-all in terms of Janie's self-identification. Intriguingly enough, they do not end up together at the novel's end. Janie is forced to defend herself by shooting and killing Tea Cake, who goes mad and attempts to kill her after contracting rabies from a dog bite. Hurston chooses to end the novel in this manner in order to emphasize that Janie ends up standing alone, rather than in a man's arms, evidence of her fulfilled quest for autonomy, a necessary component of the biracial female identity Larsen and Hurston advocate.

A more important component of Janie's biracial female identity, however, is the need to embrace all of one's "kinfolks," which she discussed with Mrs. Turner earlier. Embracing "kinfolks" from both races, for Janie, means drawing on all facets of one's history and culture to learn and discover and grow as an individual. For example, although Janie loves her grandmother, she eventually resists her way of life, though she draws from her experiences in order to define her own path as a woman. A particularly poignant scene in the novel comes just after Joe's death, when Janie examines her life and admits that "Nanny had taken the biggest thing God ever made, the horizon... and 
pinched it in to such a little bit of a thing that she could tie it about her granddaughter's neck tight enough to choke her" (Hurston 89). Here, Janie suggests that Nanny's history of racial/gender oppression through slavery and rape prompted her to limit Janie's options by forcing her into a marriage for her supposed "protection." Janie, however, realizes that in forcing her to live out a prescribed racial/gender role, she actually subjected her granddaughter to further oppression. Janie uses her knowledge of the past to overcome oppression and construct a vital, positive self-definition.

Moreover, Hurston revises the tragic mulatta tradition in that Janie does not replicate her mother's "tragic" experiences (as Xarifa, specifically, replicates her mother Rosalie's tragedy in "The Quadroons") but rather, learns and grows from them. Although Janie is the product of generations of rape and dominance by the white patriarchy, she does not succumb to the same fate as her ancestors. Furthermore, while she does not live in a white community, she never rejects that aspect of her heritage. "White folks" (142) are neither revered as worthy of emulation nor cast aside as unanimous oppressors. They are simply Janie's acknowledged "kinfolks" as well. Hurston makes Janie's multiple cultural alliances particularly evident during her trial for Tea Cake's murder, during which numerous white people support her. Dr. Simmons, a friend of both Janie and Tea Cake, testifies on her behalf. More intriguingly, Janie notices that "[e]ight or ten white women had come to look at her too" (185). Because Tea Cake's friends have turned against her, Janie feels alone and suddenly wishes that "she could make [the white women] know how it was instead of those menfolks" (185). Janie's desire to speak to the women and make them understand her plight indicates that she believes they will identify with one another as women, regardless of racial affiliation. 
Her assumption is correct, as evidenced in the fact that her supporters "cried and stood around her like a protecting wall" after she is freed of all charges (188). Janie is extremely grateful for "the kind white friends who had realized her feelings," and her expressed desire to embark on a "great journey to the horizons in search of people" indicates that her future might include embracing them as well $(188,89)$.

Because Hurston clearly posits the need for multiplicity throughout Their Eyes, Janie's final assertion to Pheoby that "you got tuh go there tuh know there" (192) can easily be read as a direct comment against essentialism. In other words, Janie feels that one must not make ungrounded assumptions about other people, but must discover life for him/herself. Moreover, Janie's analogy of love as being 'lak de sea...It's uh movin' thing, but still and all, it takes its shape from de shore it meets, and it's different with every shore" (191) can be applied to her racial identity as well, in that it is constantly changing. Hurston presents Janie as a woman who refuses to submit to limiting categorization based on race or gender, which includes negative stereotypes of black female sexuality and black essentialism. Additionally, by refusing to be "tragically colored," Janie embodies the "new and improved" mulatta character that Larsen and Hurston attempt to fashion. 


\section{Conclusion}

Cary Wintz asserts in Black Culture and the Harlem Renaissance that in their novels Quicksand, Passing, and Their Eyes Were Watching God, Nella Larsen and Zora Neale Hurston "explored the limits confronting black women in the 1920s and 1930s, and they attempted to expand the possibilities" (216). In particular, these authors staunchly challenge the historical characterization of the "tragic mulatta" as a weak, pathetic victim of a divided racial self, because of the essentialist notions of race and womanhood that her stereotypical categorization perpetuates and reinforces. In terms of "expanding the possibilities," Larsen and Hurston recognize the potential of the mulatta character to become a vehicle for analyzing the resistance of all females against stereotypical categorization, in terms of race, gender, and class.

As such, they advocate the construction of a "biracial female identity" for their mulatta protagonists, which acknowledges all facets of one's racial/cultural heritages, as well as asserting the need for liberation from historical mandates of "true womanhood" that lend to the repression and subjugation of women. While Larsen's mulatta characters, Helga Crane, Irene Redfield, and Clare Kendry, move toward a biracial female selfidentification, it is Hurston's protagonist, Janie Crawford, who actually embodies the goal of a multiple identity. Because of her ability to attain/maintain this goal, Janie finds solutions to the problems of self-image, sexuality, marriage, patriarchal oppression, and womanhood raised in Larsen's novels, and asserts an autonomous self, free of all racial and gender confinements. 
Als, Hilton. Introduction. Clotel, or, The President's Daughter. Ed. Graham Hodges. New York: Random House, 2000.

Andrews, William L. Foreword. The House Behind the Cedars. Athens, GA: The University of Georgia Press, 2000.

Barbeito, Patricia Felisa. "Making Generations' in Jacobs, Larsen, and Hurston: A Genealogy of Black Women's Writing." American Literature 70 (1998): 365-95.

Barnett, Pamela E. "'My Picture of You Is, After All, the True Helga Crane': Portraiture and Identity in Nella Larsen's Quicksand." Signs 20 (1995): 575-600.

Batker, Carol. "'Love me like I like to be': The Sexual Politics of Hurston's Their Eyes Were Watching God, the Classic Blues, and the Black Women's Club Movement." African American Review 32 (1998): 199-211.

Berzon, Judith R. Neither White Nor Black: The Mulatto Character in American Fiction. New York: New York University Press, 1978.

Brown, William Wells. Clotel, or, The President's Daughter. Ed. Graham Hodges. New York: Random House, 2000.

Carby, Hazel V. Reconstructing Womanhood: The Emergence of the Afro-American Woman Novelist. Oxford: Oxford University Press, 1987.

Chandler, Karen M. "Nella Larsen's Fatal Polarities: Melodrama and Its Limits in Quicksand." CLA Journal 42 (1998): 24-47.

Chesnutt, Charles W. The House Behind the Cedars. Athens, GA: The University of Georgia Press, 2000.

Child, Lydia Maria. "The Quadroons." The Online Archive of Nineteenth-Century U.S. Women's Writings. Ed. Glynis Carr. Posted: Summer 1997. Bucknell University. 1 May 2003. <http://www.facstaff.bucknell.edu/gcarr/19cUSWW/LB/Q.html>. . "Slavery's Pleasant Homes." The Online Archive of Nineteenth-Century U.S. Women's Writings. Ed. Glynis Carr. Posted: Summer 1997. Bucknell University. 1 May 2003. <http://www.facstaff.bucknell.edu/gcarr/19cUSWW/LB/SPH.html>.

Collins, Patricia Hill. Black Feminist Thought: Knowledge, Consciousness, and the Politics of Empowerment. New York \& London: Routledge, 2000.

Comas-Diaz, Lillian. "LatiNegra: Mental Health Issues of African Latinas." The 
Multiracial Experience: Racial Borders as the New Frontier.

Ed. Maria P.P. Root. London: Sage Publications, 1996. 167-190.

Cutter, Martha J. "Sliding Significations: Passing as a Narrative and Textual Strategy in Nella Larsen's Fiction." Passing and the Fictions of Identity. Ed. Elaine K.

Ginsberg. Durham \& London: Duke University Press, 1996. 75-100.

Davis, Thadious M. Nella Larsen, Novelist of the Harlem Renaissance: A Woman's Life Unveiled. Baton Rouge \& London: Louisiana State University Press, 1994.

DeVere Brody, Jennifer. "Clare Kendry's 'True' Colors: Race and Class Conflict in Nella Larsen's Passing." Callaloo 15 (Fall 1992): 1053-65.

Fauset, Jessie. Comedy: American Style. College Park, MD: McGrath Publishing Company, 1969.

Flores, Toni. "Claiming and Making: Ethnicity, Gender, and the Common Sense in Leslie Marmon Silko's Ceremony and Zora Neale Hurston's Their Eyes Were Watching God." Contemporary American Women Writers: Gender, Class, Ethnicity. Ed. Lois Parkinson Zamora. London \& New York: Addison Wesley Longman, 1998. 114-127.

Fox-Genovese, Elizabeth. "Slavery, Race, and the Tragic Mulatta." The Mississippi Quarterly 49 (Fall 1996): 791-817.

Gaines, Kevin K. Uplifting the Race: Black Leadership, Politics, and Culture in the Twentieth Century. Chapel Hill \& London: University of North Carolina Press, 1996.

Frazier, E. Franklin. Black Bourgeoisie: The Rise of a New Middle Class in the United States. New York: Macmillan Publishing Company, 1957.

Golden, Marita. Foreword. An Intimation of Things Distant: The Collected Fiction of Nella Larsen. Ed. Charles R. Larson. New York: Anchor Books, 1992.

Goldsmith, Meredith. "Shopping to Pass, Passing to Shop: Bodily Self-Fashioning in the Fiction of Nella Larsen." Recovering the Black Female Body: SelfRepresentations by African-American Women. Eds. Michael Bennett and Vanessa D. Dickerson. New Brunswick, NJ \& London: Rutgers University Press, 2001. 97-117.

Guy-Sheftall, Beverly. "The Body Politic: Black Female Sexuality and the NineteenthCentury Euro-American Imagination." Skin Deep, Spirit Strong: The Black Female Body in American Culture. Ed. Kimberly Wallace-Sanders. Ann Arbor: University of Michigan Press, 2002. 13-35. 
Helms, J.E. Black and White Racial Identity: Theory, Research and Practice. New York: Greenwood Press, 1990.

Hering, Frank. "Sneaking Around: Idealized Domesticity, Identity Politics, and Games of Friendship in Nella Larsen's Passing." Arizona Quarterly 57 (Spring 2001): 3560 .

hooks, bell. Ain't I A Woman: black women and feminism. Boston: South End Press, 1981.

Horton, Merrill. "Blackness, Betrayal, and Childhood: Race and Identity in Nella Larsen's Passing." CLA Journal 38 (September 1994): 31-45.

Hull, Gloria T. Color, Sex, \& Poetry: Three Women Writers of the Harlem Renaissance. Bloomington \& Indianapolis: Indiana University Press, 1987.

Hurston, Zora Neale. Dust Tracks on a Road. New York: Arno Press, 1969. Their Eyes Were Watching God. New York: HarperCollins Publishers, 1937.

Hutchinson, George. "Nella Larsen and the Veil of Race." American Literary History 9 (1997): 329-49.

. “Quicksand and the Racial Labyrinth." Soundings 80 (1997): 543-71.

Karcher, Carolyn L. The First Woman in the Republic: A Cultural Biography of Lydia Maria Child. Durham \& London: Duke University Press, 1994.

Kich, George Kitahara. "In the Margins of Sex and Race: Difference, Marginality, and Flexibility." The Multiracial Experience: Racial Borders as the New Frontier. Ed. Maria P.P. Root. London: Sage Publications, 1996. 263-276.

Knudsen, Janice L. "The Tapestry of Living: A Journey of Self-Discovery in Hurston's Their Eyes Were Watching God." CLA Journal 15 (December 1996): 214-229.

Larsen, Nella. Quicksand and Passing. Ed. Deborah E. McDowell. New Brunswick, NJ \& London: Rutgers University Press, 1986.

Lewis, Vashti Crutcher. "Nella Larsen's Use of the Near-White Female in Quicksand and Passing." Perspectives of Black Popular Culture. Ed. Harry B. Shaw. Bowling Green, OH: Bowling Green State University Popular Press, 1990. $36-45$.

"The Declining Significance of the Mulatto Female as Major Character in the Novels of Zora Neale Hurston." CLA Journal 28 (December 1984): 127-149. 
Lutes, Jean Marie. "Making Up Race: Jessie Fauset, Nella Larsen, and the African American Cosmetics Industry." Arizona Quarterly 58 (Spring 2002): 77-108.

McClendon, Jacqueline. "Nella Larsen: 1891-1964." African American Writers. Eds. Valerie Smith, Lea Baechler \& A. Walton Litz. New York: Macmillan Publishing Company, 1991. 263-272.

McCord, Louisa S.C. "Review of Uncle Tom's Cabin." Southern Quarterly Review 23 (January 1853): 113-117.

McDowell, Deborah E. Introduction. Quicksand and Passing. Ed. Deborah E. McDowell. New Brunswick, NJ \& London: Rutgers University Press, 1986.

McKay, Nellie. "'Crayon Enlargements of Life': Zora Neale Hurston's Their Eyes Were Watching God as Autobiography." New Essays on Their Eyes Were Watching God. Ed. Michael Awkward. Cambridge: Cambridge University Press, 1990. 51-70.

Monda, Kimberly. "Self-Delusion and Self-Sacrifice in Nella Larsen's Quicksand." African American Review 31 (1997): 23-39.

Palumbo-DeSimone, Christine. "Race, Womanhood, and the Tragic Mulatta: An Issue of Ambiguity." Multiculturalism: Roots and Realities. Ed. C. James Trotman. Bloomington \& Indianapolis: Indiana University Press, 2002. 125-136.

Peters, Pearlie M. "'Ah Got the Law in My Mouth': Black Women and Assertive Voice In Hurston's Fiction and Folklore." CLA Journal 37 (March 1994): 293-302.

Racine, Maria J. "Voice and Interiority in Zora Neale Hurston's Their Eyes Were Watching God." African American Review 28 (Summer 1994): 283-292.

Root, Maria. Racially Mixed People in America. Newbury Park, CA: Sage, 1992.

Smith, Barbara. "Racism and Women's Studies." All the Women are White, All the Blacks are Men, But Some of Us are Brave. Eds. Gloria Hull, et.al. Old Westbury, NY: The Feminist Press, 1982.

Sollors, Werner. Neither Black Nor White Yet Both: Thematic Explorations of Interracial

Literature. Cambridge \& London: Harvard University Press, 1997.

Stowe, Harriet Beecher. Uncle Tom's Cabin. Ed. Jean Fagan Yellin. Oxford: Oxford University Press, 1998.

Strauss, Anselm. Mirrors and Masks: The Search for Identity. Glencoe, IL: Free Press, 1959 . 
Tate, Claudia. "Desire and Death in Quicksand, by Nella Larsen." American Literary History 7 (Summer 1995): 234-260.

Vickers, Anita M. "The Reaffirmation of African-American Dignity Through the Oral Tradition in Zora Neale Hurston's Their Eyes Were Watching God." CLA Journal 37 (March 1994): 303-315.

Wall, Cheryl A. Women of the Harlem Renaissance. Bloomington \& Indianapolis: Indiana University Press, 1995.

Weisman, Jan R. "An 'Other' Way of Life: The Empowerment of Alterity in the Interracial Individual." The Multiracial Experience: Racial Borders as the New Frontier. Ed. Maria P. P. Root. London: Sage Publications, 1996. 152-164.

Welter, Barbara. "The Cult of True Womanhood: 1820-1860." American Quarterly 18 (Summer 1966): 151-74.

White, Deborah Gray. Ar'n't I a Woman?: Female Slaves in the Plantation South. New York \& London: W.W. Norton \& Company, 1985.

Williams, Bettye J. "Nella Larsen: Early Twentieth-Century Novelist of Afrocentric Feminist Thought." CLA Journal 39 (December 1995): 165-78.

Williams, Teresa. "Race as Process: Reassessing the 'What Are You?' Encounters of Biracial Individuals." The Multiracial Experience: Racial Borders as the New Frontier. Ed. Maria P. P. Root. London: Sage Publications, 1996. 191-210.

Wintz, Cary D. Black Culture and the Harlem Renaissance. Houston: Rice University Press, 1988.

Yarborough, Richard. "Strategies of Black Characterization in Uncle Tom's Cabin and the Early Afro-American Novel." New Essays on Uncle Tom's Cabin. Ed. Eric J. Sundquist. Cambridge: Cambridge University Press, 1986. 45-84.

. "The First-Person in Afro-American Fiction." Afro-American

Literary Study in the 1990s. Ed. Houston A. Baker, Jr. and Patricia Redmond. Chicago \& London: University of Chicago Press, 1989. 105-21.

Yellin, Jean Fagan. "Doing it Herself: Uncle Tom's Cabin and Woman's Role in the Slavery Crisis." New Essays on Uncle Tom's Cabin. Ed. Eric J. Sundquist. Cambridge: Cambridge University Press, 1986. 85-105.

Women \& Sisters: The Antislavery Feminists in American Culture. New Haven \& London: Yale University Press, 1989.

Zanger, Jules. "The 'Tragic Octoroon' in Pre-Civil War Fiction." American Quarterly 
18 (Spring 1966): 63-70. 